
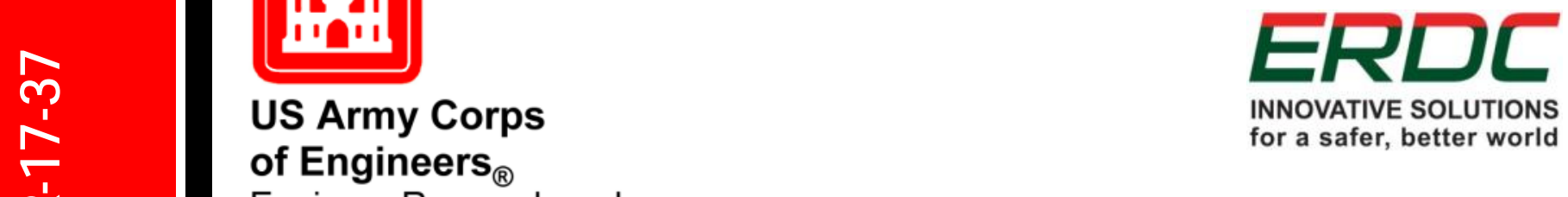
INNOVATIVE SOLUTIONS for a safer, better world Engineer Research and Development Center

\title{
Material Selection for Bumpers and Fenders for Lock Gates and Guidewalls
}

Stuart D. Foltz and Richard G. Lampo

November 2017

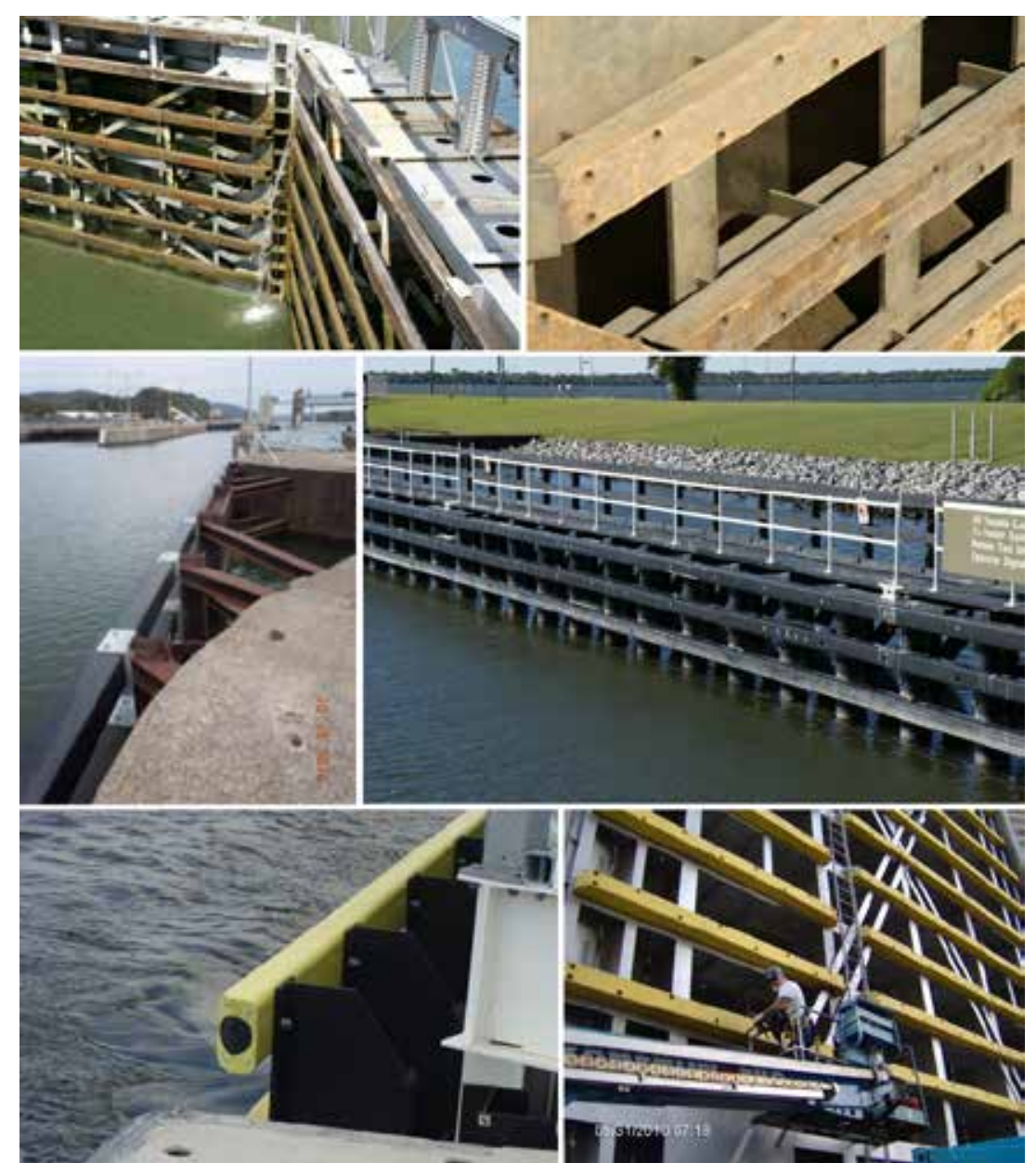


The U.S. Army Engineer Research and Development Center (ERDC) solves the nation's toughest engineering and environmental challenges. ERDC develops innovative solutions in civil and military engineering, geospatial sciences, water resources, and environmental sciences for the Army, the Department of Defense, civilian agencies, and our nation's public good. Find out more at wwwerdc.usacearmy.mil.

To search for other technical reports published by ERDC, visit the ERDC online library at http:/ / acuc.sdp.sirsi.net/ dient/ default. 


\title{
Material Selection for Bumpers and Fenders for Lock Gates and Guidewalls
}

\author{
Stuart D. Foltz and Richard G. Lampo \\ U.S. Army Engineer Research and Development Center (ERDC) \\ Construction Engineering Research Laboratory (CERL) \\ 2902 Newmark Dr. \\ Champaign, IL 61824
}

Final Report

Approved for public release; distribution is unlimited.

Prepared for Headquarters, U.S. Army Corps of Engineers

Washington, DC 20314-1000

Under Navigation Structures Project "FRP Composites for the Rapid Repair and Maintenance of Navigation Gates and Structures" 


\section{Abstract}

The U.S. Army Corps of Engineers owns or operates 236 locks at 191 sites, more than half of which have surpassed their 50-year design life. There are increasing concerns about their continued safe, reliable operation into the future, especially regarding the adequacy, cost, and effectiveness of routine maintenance, repair, and rehabilitation. Lock gate and guidewall fenders are components that protect locks and gates from barge impacts, and that are consequently subject to impact damage as well as environmental degradation. Fenders may be constructed of any of several materials, most commonly wood, steel, or plastic. The Corps has used fenders made of plastic and composite alternatives to wood and steel shapes with varying levels of success. It is useful to evaluate these newer plastic/ composite materials, and to compare them with their traditional counterparts to determine their relative merits. This preliminary study, based on survey results, was undertaken to initiate an investigation into and discussion of the materials and designs currently used for lock gate and guidewall fenders, with a focus on their relative advantages and disadvantages.

DISCLAIMER: The contents of this report are not to be used for advertising, publication, or promotional purposes. Citation of trade names does not constitute an official endorsement or approval of the use of such commercial products. All product names and trademarks cited are the property of their respective owners. The findings of this report are not to be construed as an official Department of the Army position unless so designated by other authorized documents. 


\section{Contents}

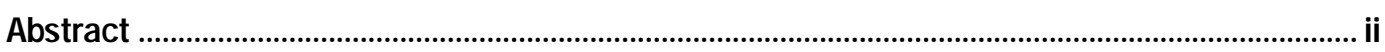

Figures and Tables..................................................................................................................iv

Preface

1 Introduction ...........................................................................................................................

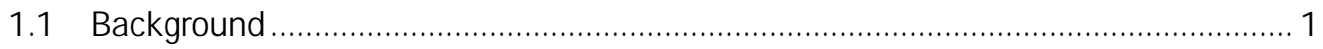

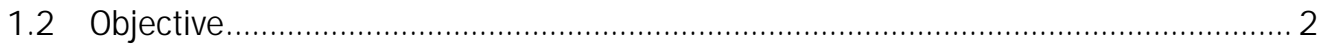

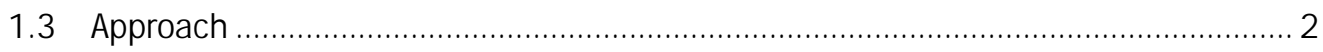

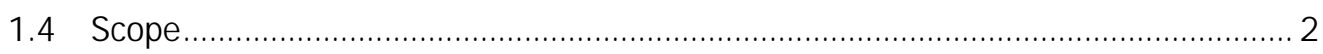

2 Review and Discussion of Fender Materials and Applications..............................................

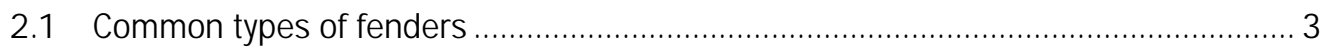

2.2 Advantages and disadvantages of material and design options ............................. 11

2.2.1 Energy absorption and abrasion..........................................................................11

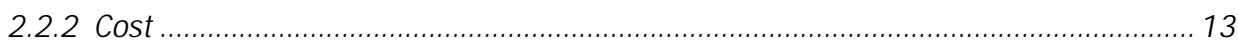

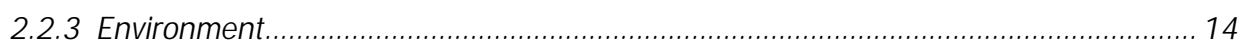

2.2.4 Durability (impact and rubbing) ..............................................................................

2.2.5 Bolts and attachments............................................................................................ 16

2.2.6 Temination design .................................................................................................. 18

2.2.7 Installation and removal ...................................................................................... 19

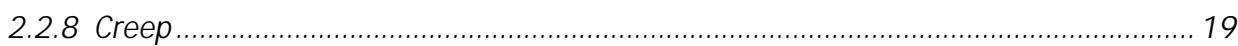

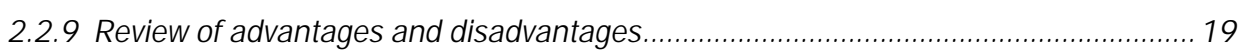

2.2.10 Louisville District best practices survey................................................................ 22

2.3 Common field usage guidance for plastic-based lumber and timbers.....................22

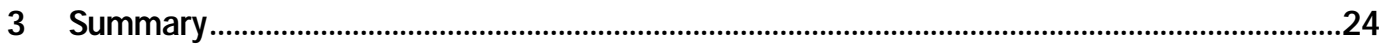

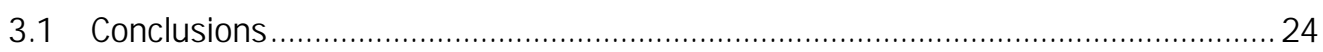

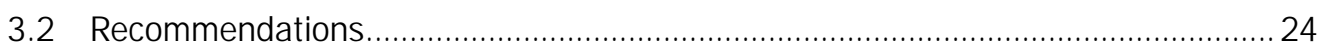

Appendix A: Additional Photographs of Miter Gate and Guidewall Fenders ..................................26

Appendix B: Photographs of Damaged Fenders at Greenup L\&D ...............................................32

Appendix C: Best Practices Meetings for Fenders ....................................................................35

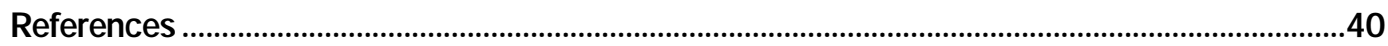

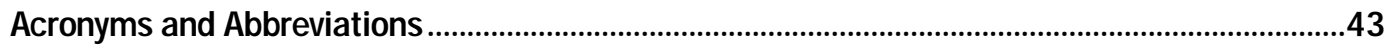

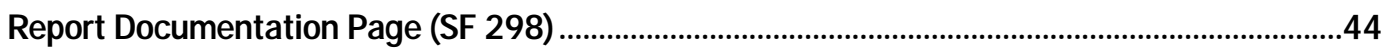




\title{
Figures and Tables
}

\author{
Figures
}

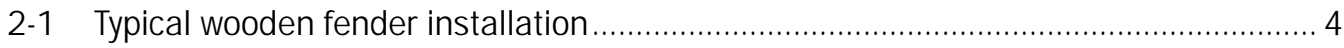

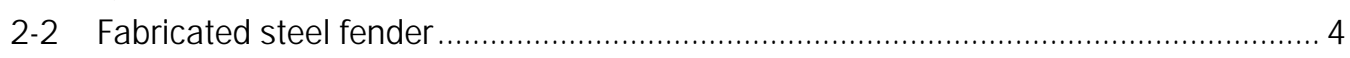

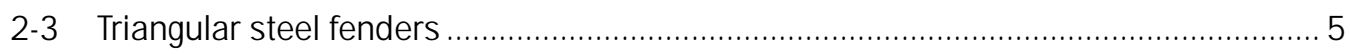

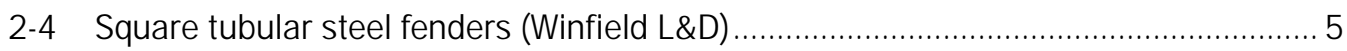

2-5 Polyethylene and rubber sandwich fender design .................................................... 6

2-6 Layered UHMWPE and elastomeric fenders (Olmsted L\&D)....................................... 6

2-7 Layered fender design with steel tube (McAlpine L\&D) .............................................. 7

2-8 Layered fender design with steel I and T sections (Greenup L\&D) ............................ 8

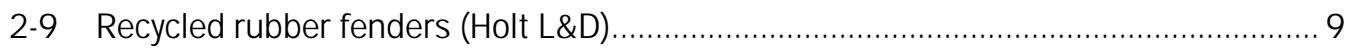

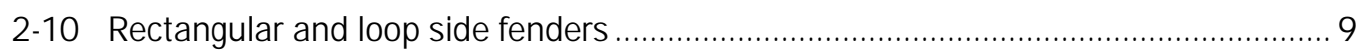

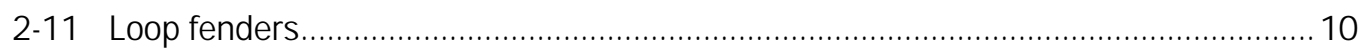

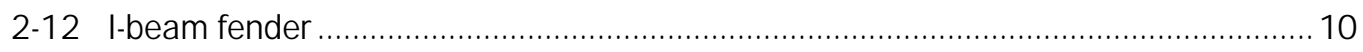

2-13 l-beam fender design ..................................................................................... 11

2-14 Deteriorated wood fenders and one replacement HDPE fender .................................. 14

2-15 Kentucky Lock upstream approach wall with yellow fenders for better visibility................................................................................................................ 15

2-16 HDPE timbers with circular less dense and softer core......................................... 17

2-17 Approach walls at the Emsworth Locks \& Dams, Pittsburgh, PA ............................... 17

2-18 Fenders at Lockport Lock and Dam, Lockport, IL .................................................. 18

2-19 View of typical plate deformation and broken weld at the fender guard transition (Greenup L\&D)

2-20 Composite rebar reinforced HDPE timbers. Note yellow color throughout the

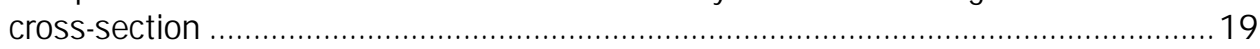

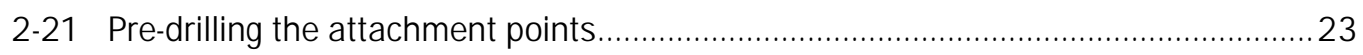

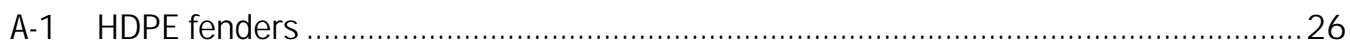

A-2 Installation of HDPE fenders colored yellow for visibility ..........................................26

A-3 Fender repairs. Notice vegetation growing out of the timber .....................................27

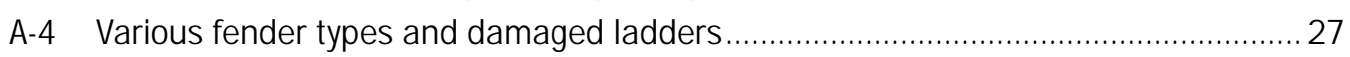

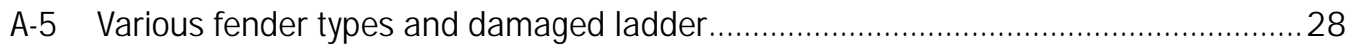

A-6 Approach wall with yellow HDPE fenders (Kentucky Lock) ......................................28

A-7 Approach wall with HDPE fenders (Lake Borgne Surge Barrier).................................29

A-8 Guidewall with HDPE fenders (Port Canaveral Locks) ................................................29

A-9 Composite plastic bumper with polyethylene core and FRP reinforcement ................30

A-10 Deteriorated wall due to barge rubbing (Ohio River Lock \#52) ...................................30

A-11 UHMWPE panel on deteriorated armor wall (Ohio River Lock \#52) .............................. 31

A-12 HDPE timber with typical void formations in the center core ..................................... 31

B-1 Greenup Lock and Dam, main chamber upstream river wall leaf, view of damaged area 
B-2 Greenup Lock and Dam, main chamber upstream river wall leaf, view of sheared off machine bolt. Most bolts are bent or sheared off, but stayed in place 33

B-3 View of gouges in UHMW fender ........................................................................... 33

B-4 Greenup Lock and Dam, main chamber upstream river wall leaf, view of bent

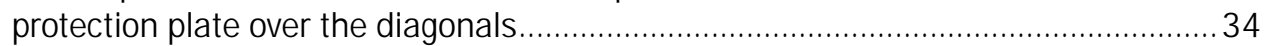

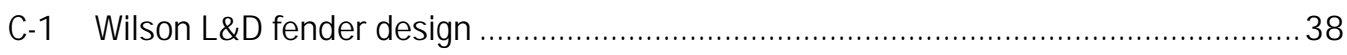

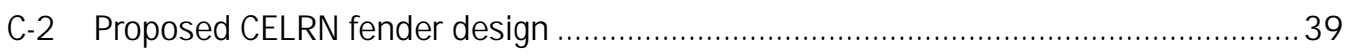

\section{Tables}

2-1 Some typical approximate costs reported during the survey..................................13

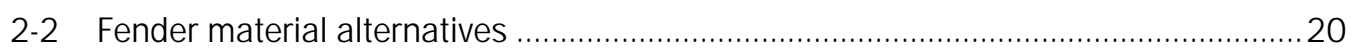




\section{Preface}

This study was conducted for Headquarters, U.S. Army Corps of Engineers (USACE) under Navigation Structures Project "FRP Composites for the Rapid Repair and Maintenance of Navigation Gates and Structures," Work Items L3L381, 5004DJ , and 09G181. The technical monitor was William J. Lillycrop, Technical Director, Navigation.

The work was performed under the direction of the Materials and Structures Branch (CFM) of the Facilities Division (CF), U.S. Army Engineer Research and Development Center - Construction Engineering Research Laboratory (ERDC-CERL). The Principal Investigator (PI) was Richard G. Lampo, CEERD-CFM. At the time of publication, Vicki VanBlaricum was Chief, CEERD-CFM; Donald K. Hicks was Chief, CEERD-CF; and Kurt Kinnevan was the Technical Director for Installations. The Deputy Director of ERDC-CERL was Dr. Kirankumar Topudurti, and the Director was Dr. Ilker Adiguzel.

COL Bryan S. Green was Commander of ERDC, and Dr. J effery P. Holland was the Director. 


\section{Introduction}

\subsection{Background}

The U.S. Army Corps of Engineers (USACE) owns or operates 236 locks at 191 sites (HQUSACE 2016). Although the locks at these sites generally perform reliably, more than half of these structures have surpassed their 50-year design life, and as such, there are increasing concerns about their continued safe, reliable operation. Specifically, questions exist regarding the adequacy, cost, and effectiveness of routine maintenance, repair, and rehabilitation.

Lock gate (e.g., miter and sector gates) and guidewall fenders are components that protect locks and gates from barge impacts, and that are consequently subject to impact damage as well as environmental degradation. Fenders may be constructed of any of several materials, most commonly wood, steel, or plastic. Wood was once the primary material chosen for lock gate and guidewall fenders, largely based on its ready availability and least first cost. In the past several decades, other materials have increasingly replaced wood - for several reasons. In some locations, wood has not performed as well as desired. Steel, which is one of the oldest alternatives to wood fenders, offers good energy absorption capacity (with the right design) and in certain environments, less susceptibility to environmental degradation than wood. More recently, various plastic and composite products have become increasingly available at prices that are competitive with those of both wood and steel.

The Corps has used fenders made of plastic and composite alternatives to wood and steel shapes with varying levels of success. The use of these materials in fender applications has also resulted in a variety of problems and a number of lessons learned. It would be useful to evaluate these newer materials, and to compare them with their traditional counterparts to determine their relative merits in terms of such selection criteria as:

- first cost

- frequency and duration of lock closures for repairs

- ability to protect the gate

- ability to survive impact(s)

- weather resistance

- maintainability

- aesthetics. 
Without a detailed inventory of miter gate, sector gate, and guidewall fenders, it is difficult to estimate the percentage of gate and approach wall fenders that are constructed of wood and alternative materials, or to evaluate their relative characteristics and performance.

\subsection{Objective}

The objective of this preliminary study was to initiate an investigation into and discussion of the materials and designs currently used for lock gate and guidewall fenders, with a focus on their relative advantages and disadvantages of the most commonly used materials and designs, ultimately to broadly assist in selection of appropriate fendering materials for particular applications.

\subsection{Approach}

This investigation consisted of a review of records of prior site visits, photos, prior research involving plastic lumber, and discussions with knowledgeable Corps employees. This survey of Corps personnel attempted to elicit the information they considered when selecting miter gate fender material, and what additional information might help them to make that decision more confidently in the future.

\subsection{Scope}

This report is intended to be a starting point for location-specific decision making, and possibly a first step leading to further research relative to the selection and use of different fender materials and systems.

The results of the surveys conducted under this effort indicated widely divergent thoughts and opinions of numerous USACE employees, whose broad knowledge of fender design, use, and performance is based largely on practical experience. Expressed differences reflect variations in environment across the United States, small differences in details, impact types and frequencies, or sometimes, one bad experience. Few, if any, of the apparently conflicting issues and concerns raised are definitively addressed in the work reported herein. 


\section{Review and Discussion of Fender Materials and Applications}

\subsection{Common types of fenders}

Fender materials used for miter gates, sector gates, and guidewalls include wood, steel, plastic, rubber, and hybrid or sandwich construction. Until the past few decades, most were made of wood (Figure 2-1). The most commonly used types of wood include pine, oak, Douglas fir, and Greenheart. Wood continues to be used and favored in many applications, even though other materials are gaining acceptance. One of the oldest alternatives to wood is steel in various forms, including rectangular tubes, fabricated shapes (Figure 2-2), and triangular shapes (Figure 2-3) and square shapes (Figure 2-4). More recently, the use of plastic timbers, typically made from either unreinforced or reinforced high density polyethylene (HDPE) or sometimes ultra-high molecular weight polyethylene (UHMWPE) and various "sandwiched" materials has become more common. The development of several American Society for Testing and Materials (ASTM) Standards for plastic lumber and composites contributed to the increased acceptance of these alternatives.

The most recent trend is a growth in the use of multi-layered fenders, typically consisting of a UHMWPE exterior with an elastomeric rubber backing (Figures 2-5 and 2-6). This design may also include a steel shape (Figures 2-7 and 2-8). The polyethylene provides a rubbing surface that is resistant to damage from scraping and minor impacts; the rubber layer is supposed to help absorb shocks; and for larger impacts, the steel shape will deform, further minimizing the energy transferred into the gate.

Mobile District reported an unusual fender type at Holt Lock and Dam that consisted of two steel rods with squares of recycled rubber "threaded" onto them (Figure 2-9), similar to towboat bumpers. The squares were approximately 6x6-in. The fender has been in service more than 13 years and reportedly performs well. Further investigation identified three companies that market products similar to this fender. Figures 2-10, 2-11, 2-12, and 2-13 show photos and design drawings of various fenders made using recycled truck and bus tires.

Appendix A includes additional photos of fenders. 
Figure 2-1. Typical wooden fender installation.

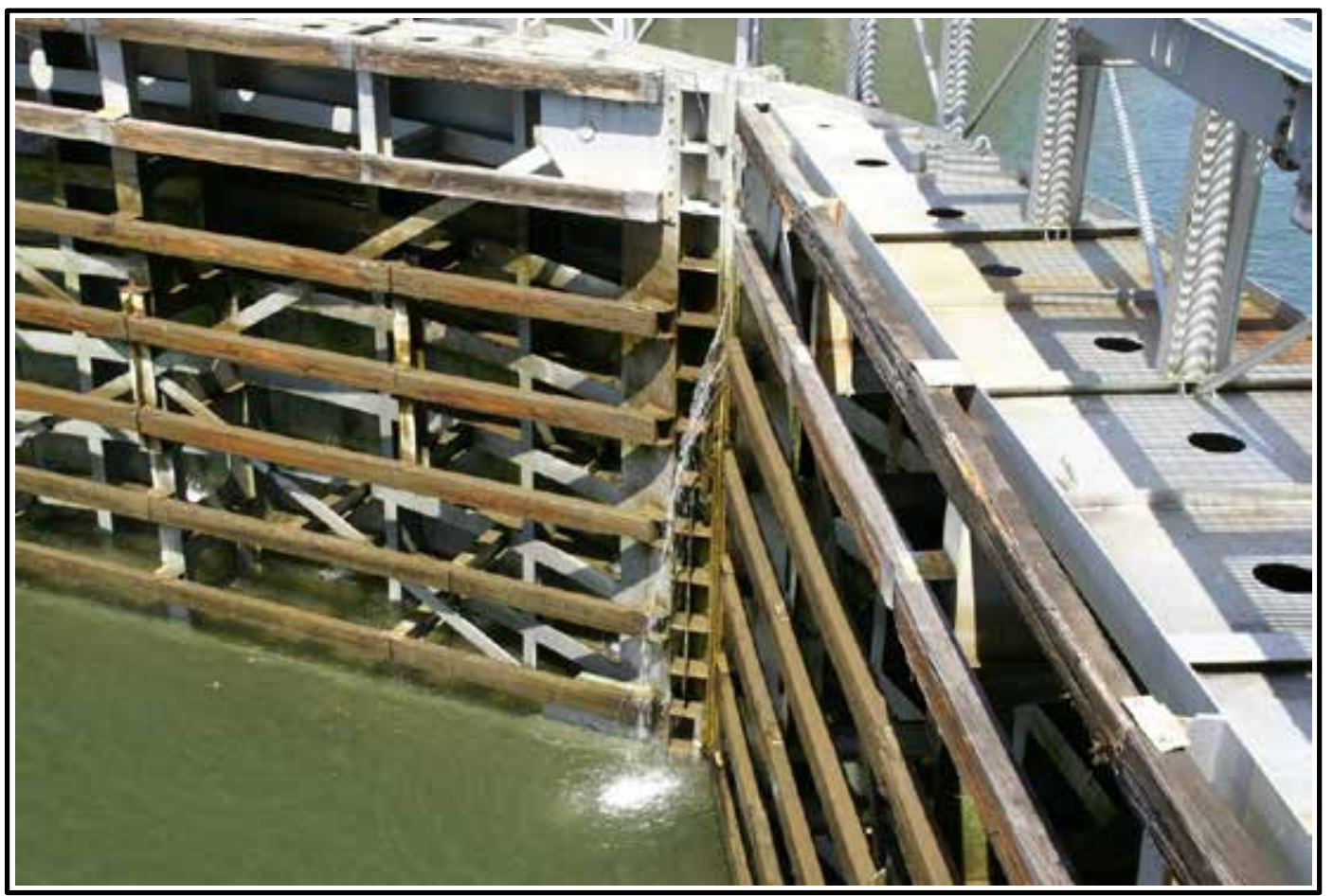

Figure 2-2. Fabricated steel fender.

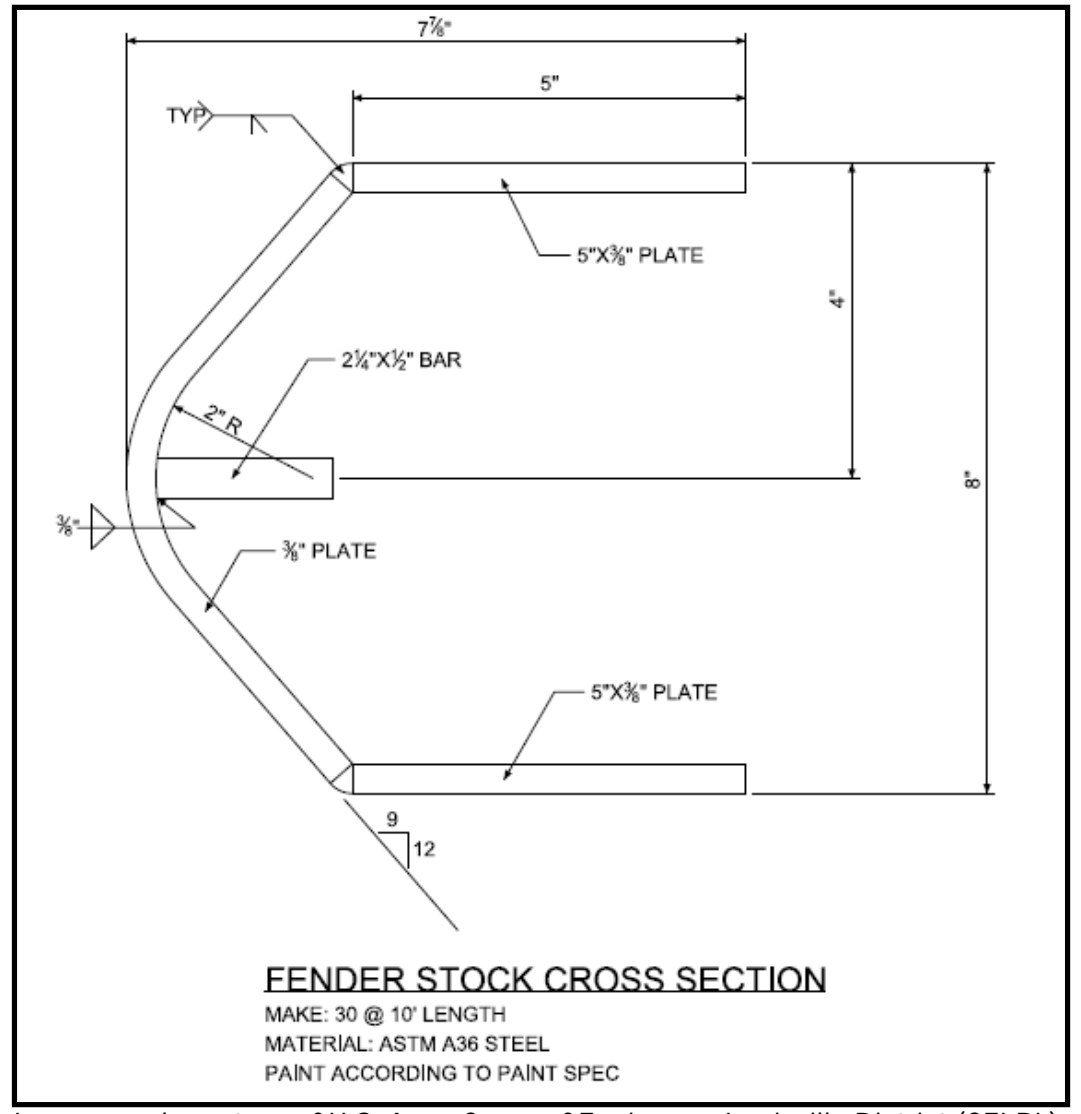

Image used courtesy of U.S. Amy Corps of Engineers, Louisville District (CELRL). 
Figure 2-3. Triangular steel fenders.

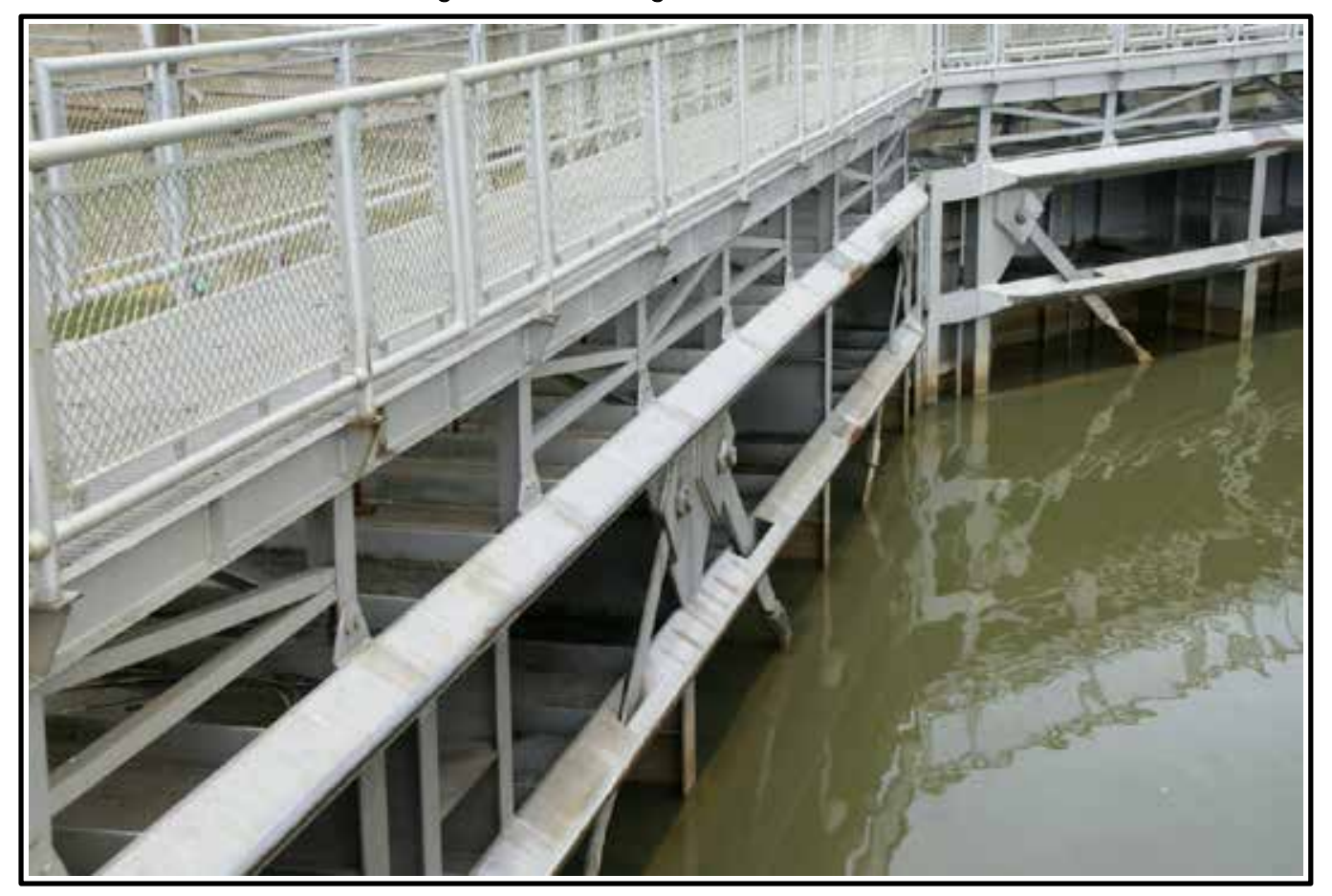

Figure 2-4. Square tubular steel fenders (Winfield L\&D).

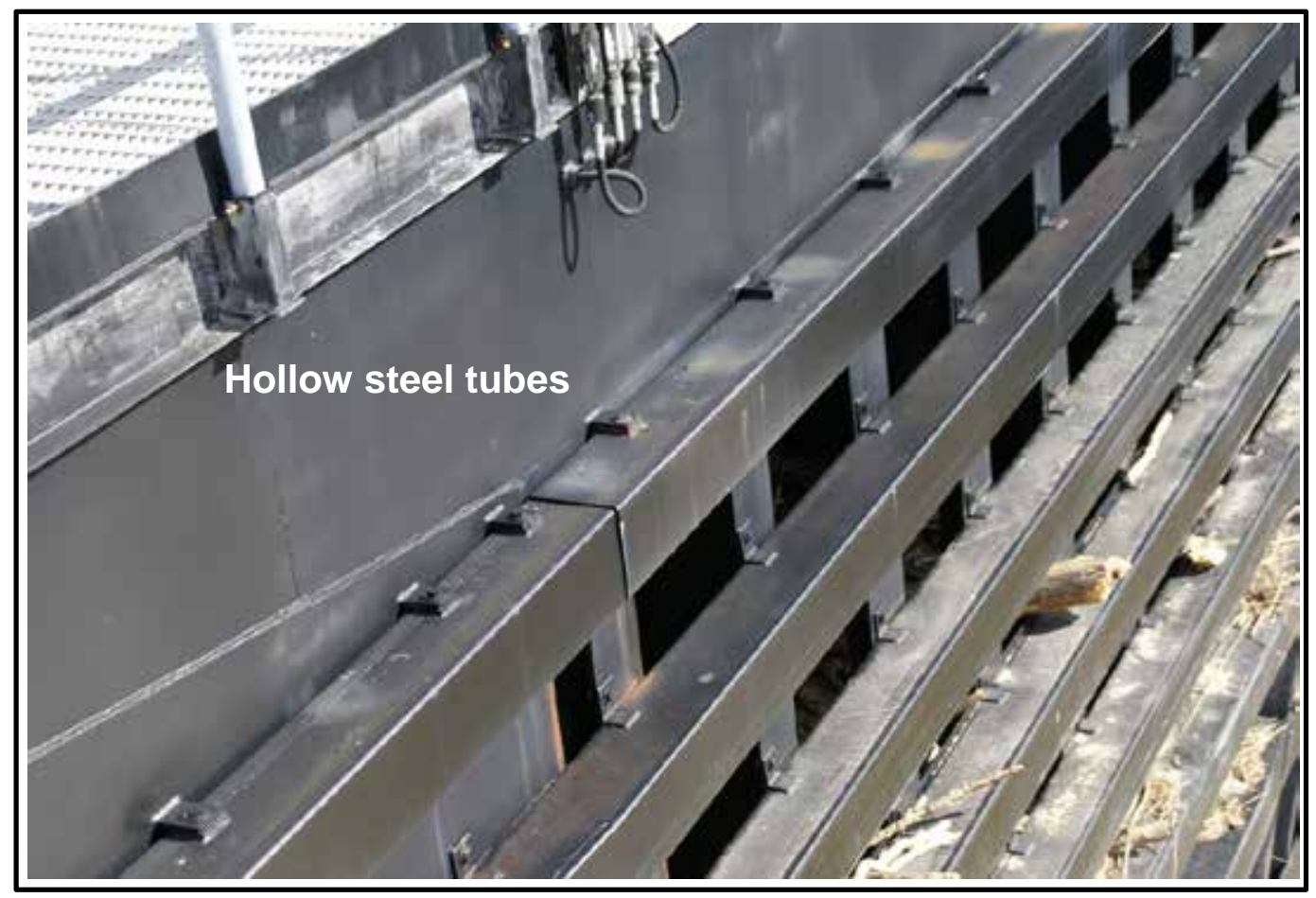


Figure 2-5. Polyethylene and rubber sandwich fender design.

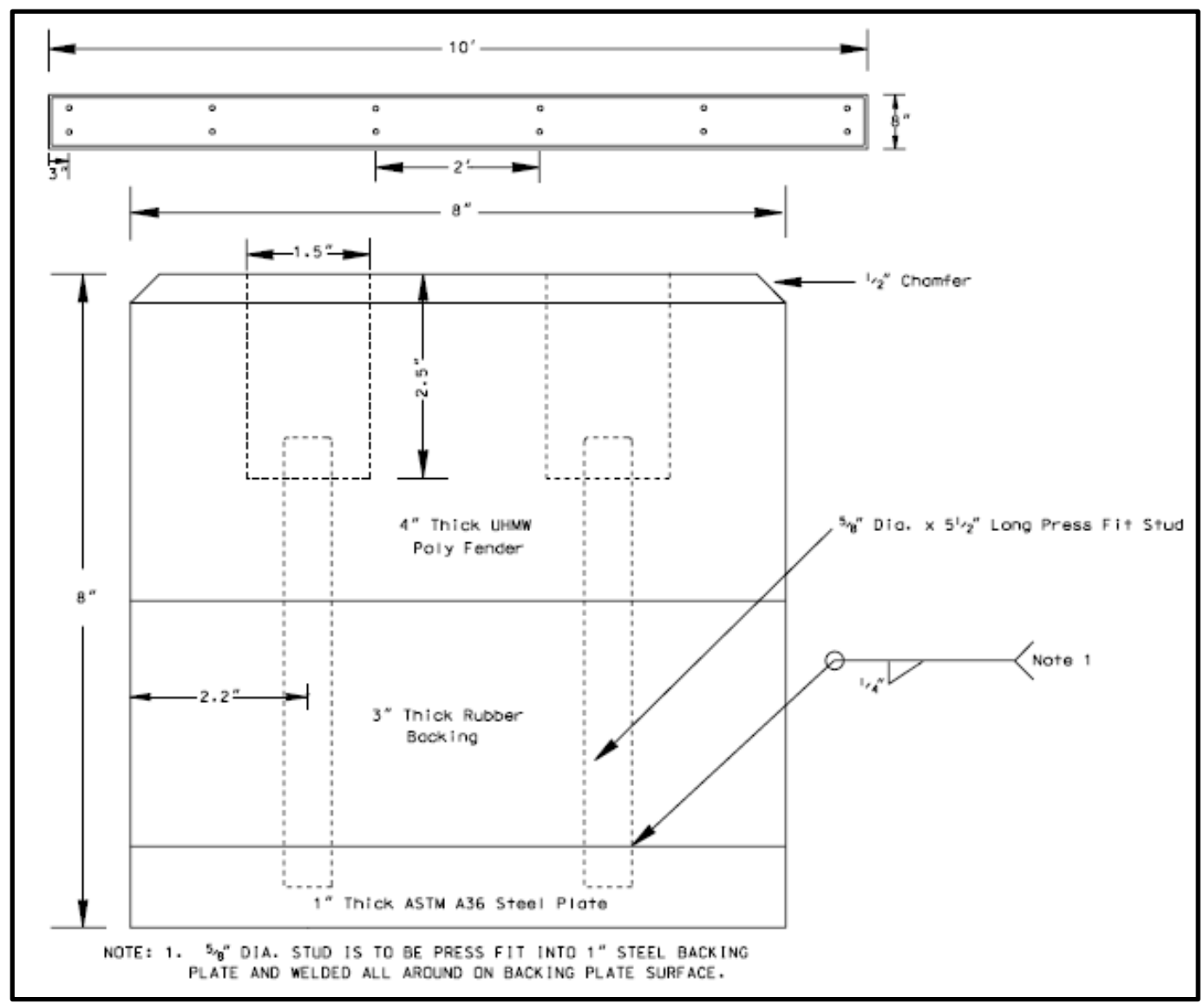

Image used courtesy of CELRL.

Figure 2-6. Layered UHMWPE and elastomeric fenders (Olmsted L\&D).

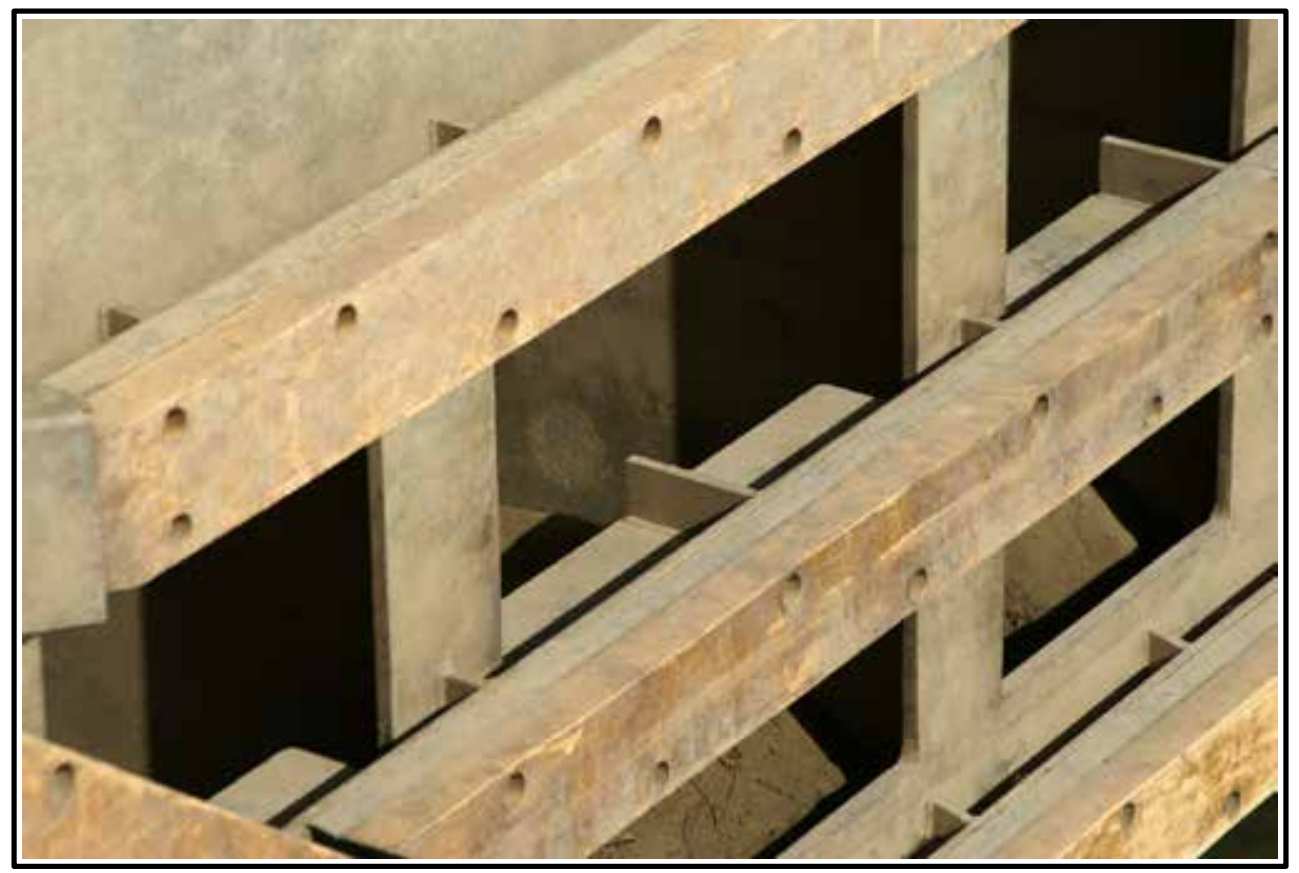


Figure 2-7. Layered fender design with steel tube (McAlpine L\&D).

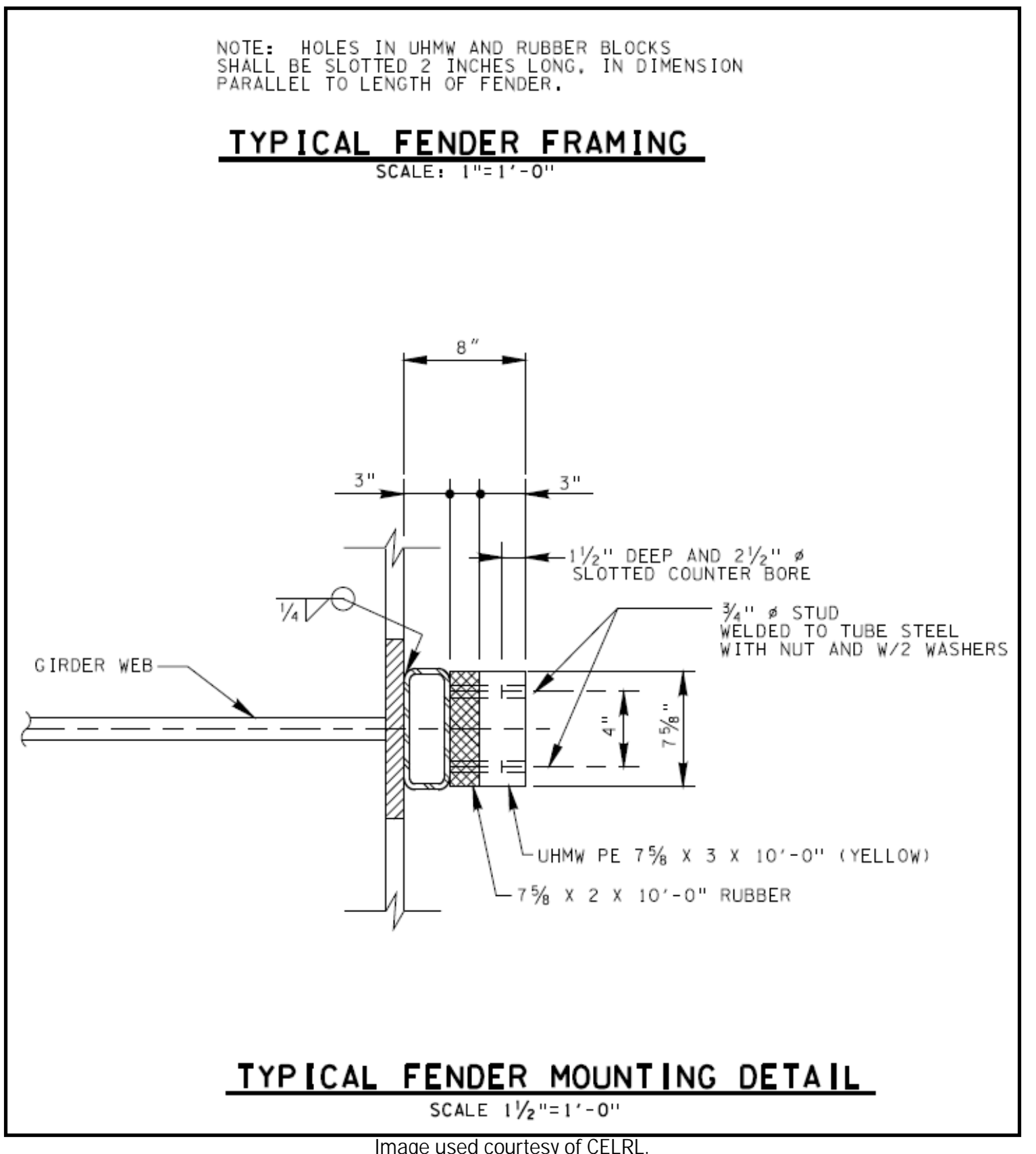

Image used courtesy of CELRL. 
Figure 2-8. Layered fender design with steel I and T sections (Greenup L\&D).

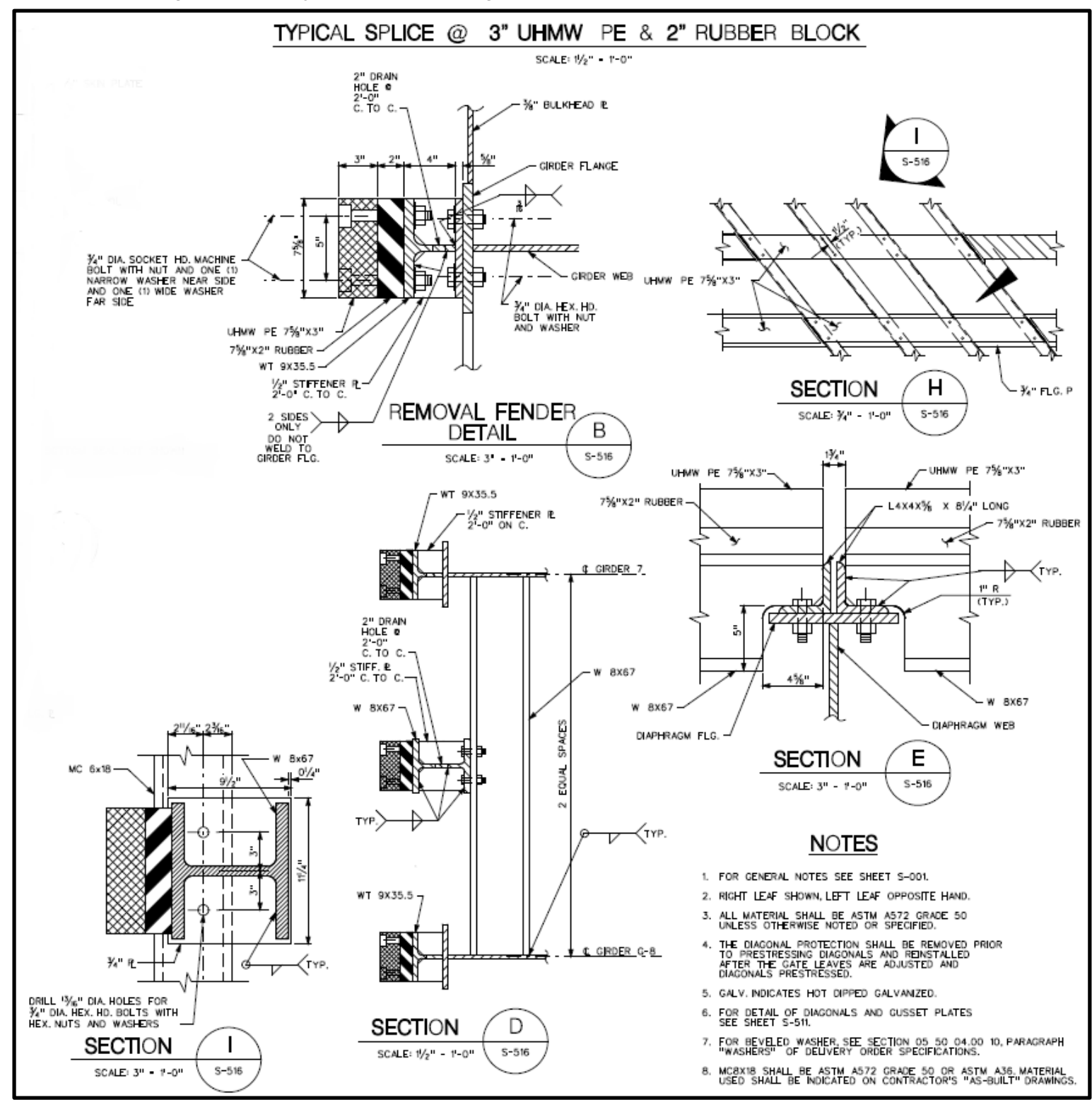

Image used courtesy of CELRL. 
Figure 2-9. Recycled rubber fenders (Holt L\&D).

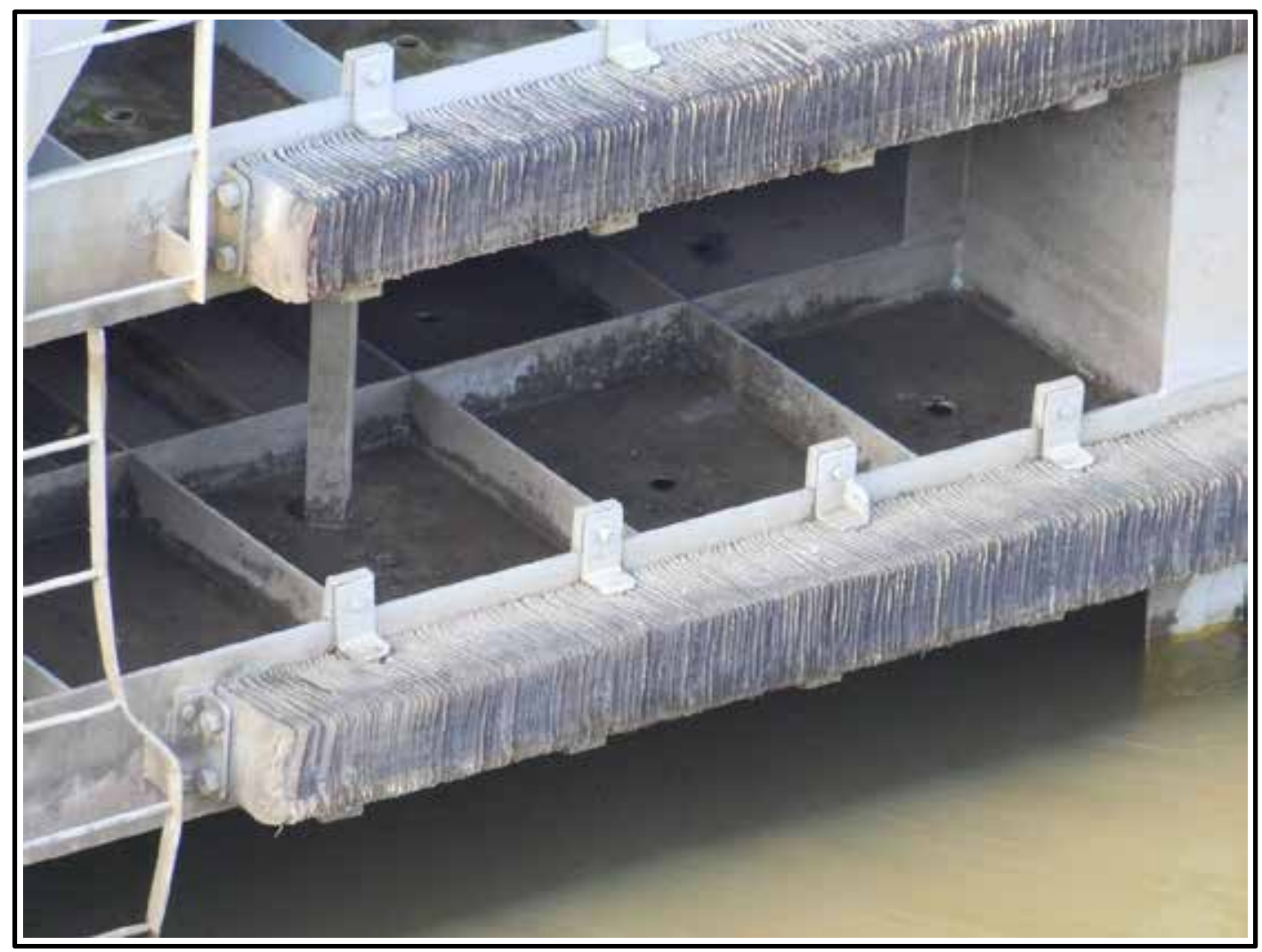

Figure 2-10. Rectangular and loop side fenders.

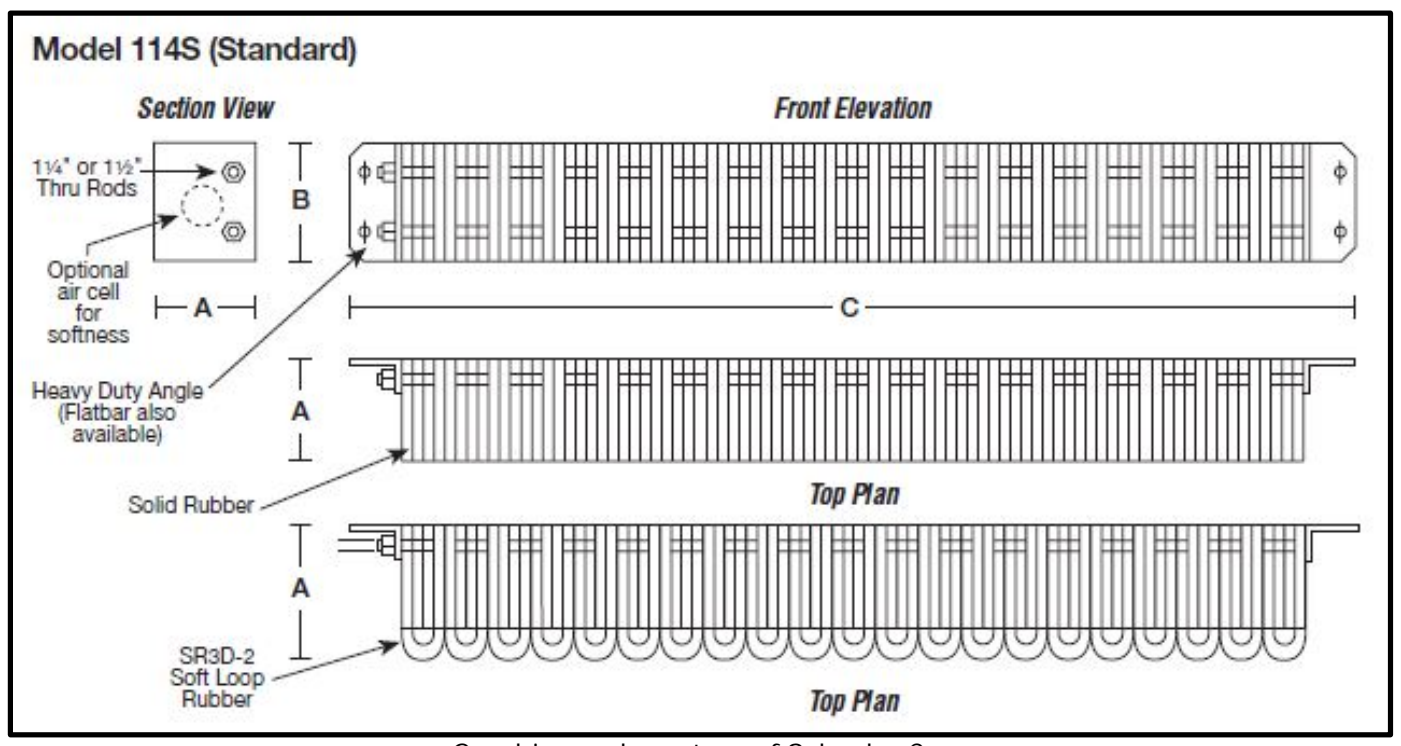

Graphic used courtesy of Schuyler Co. 
Figure 2-11. Loop fenders.

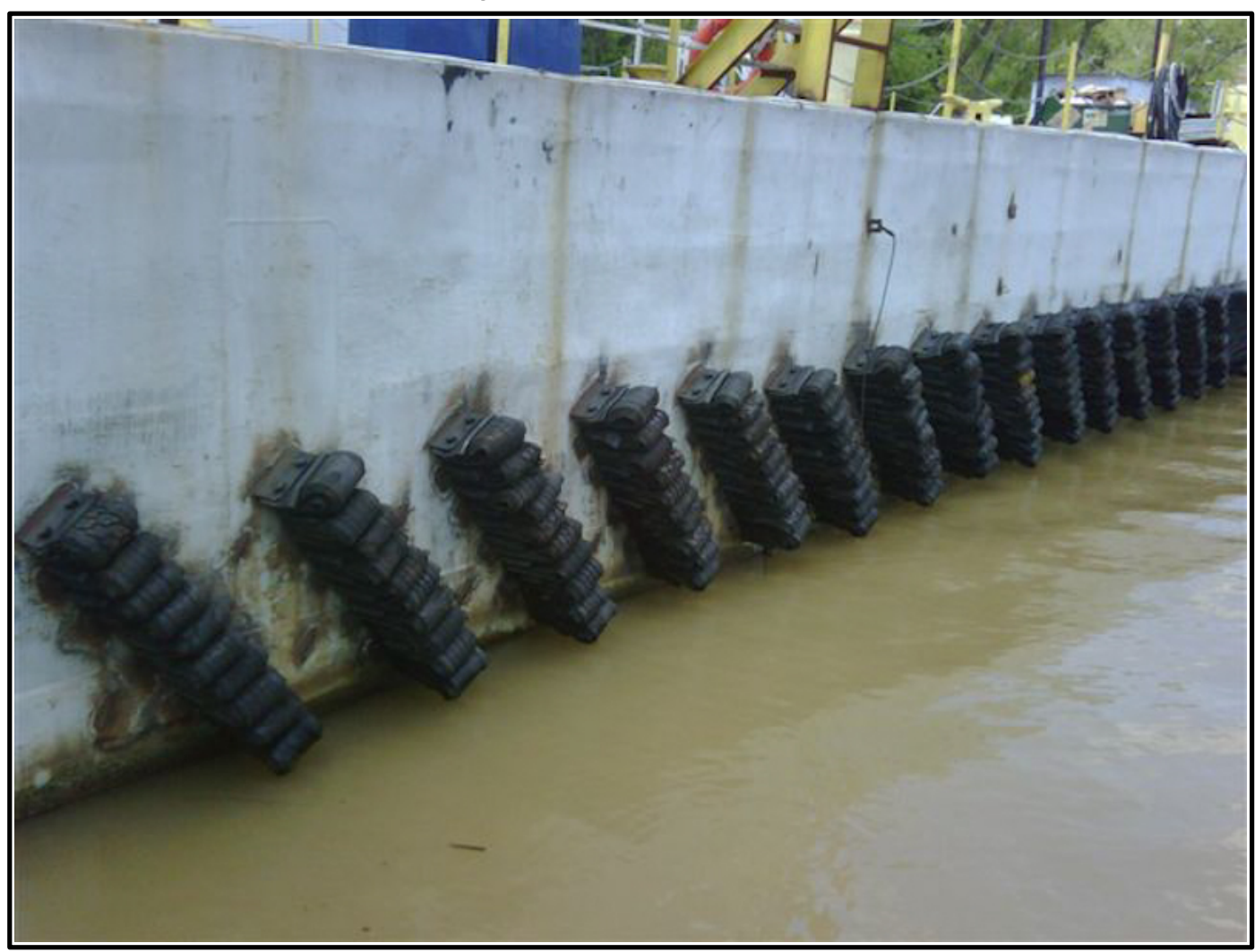

Graphic used courtesy of Schuyler Co.

Figure 2-12. I-beam fender.

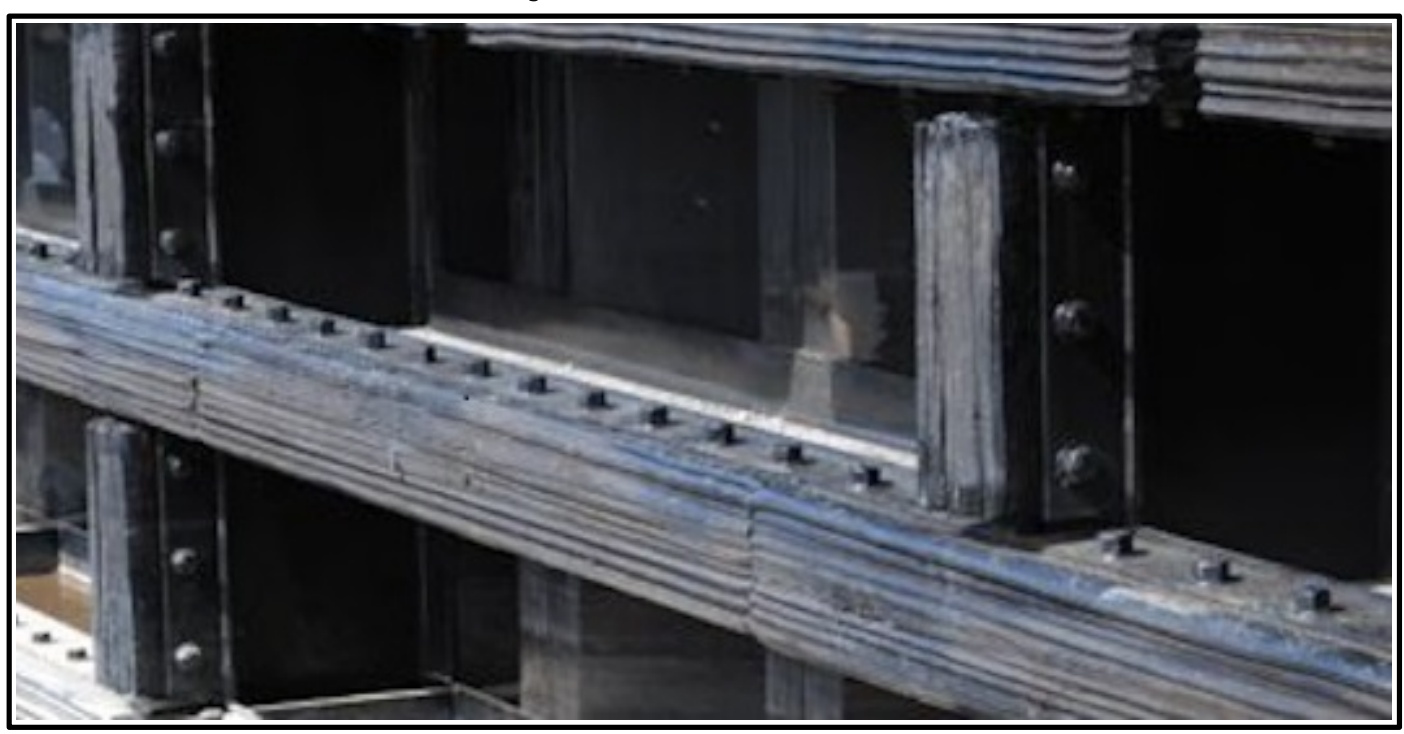

Graphic used courtesy of Schuyler Co. 
Figure 2-13. I-beam fender design.

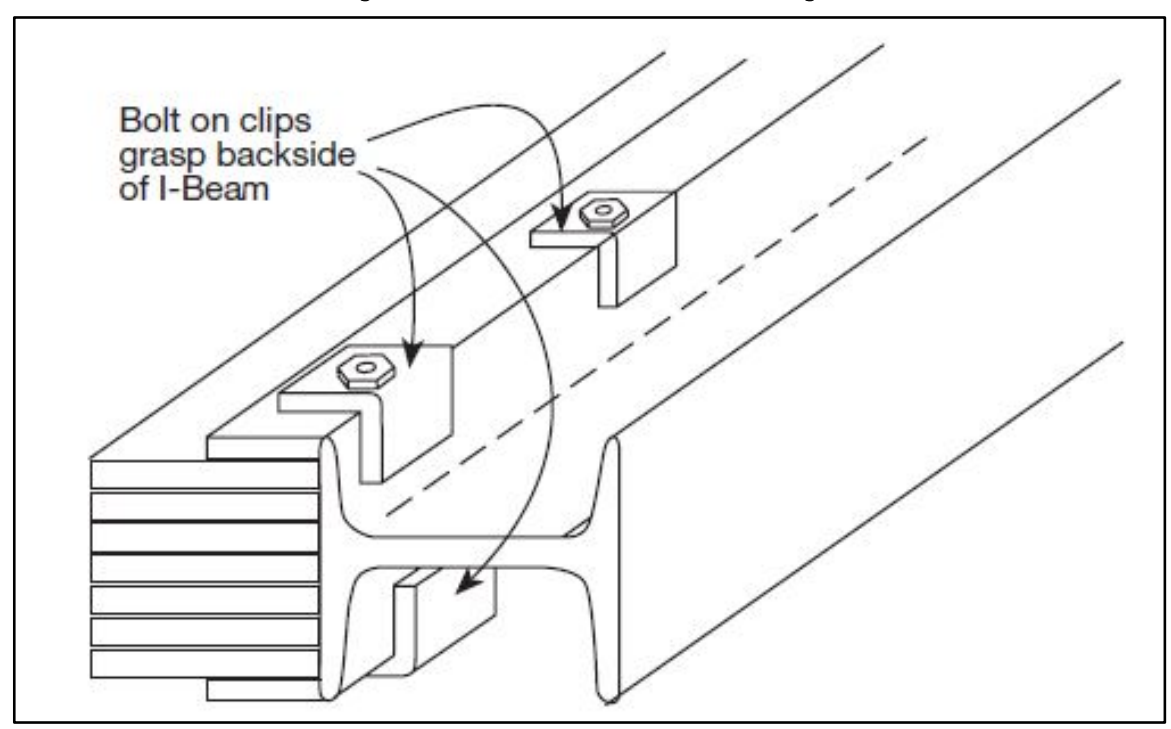

Graphic used courtesy of Schuyler Co.

\subsection{Advantages and disadvantages of material and design options}

Many materials can be used for gate and approach wall fenders. Each material has unique advantages and disadvantages that must be considered in the selection process for a particular application. The first step in selecting a fender design is to identify the advantages and disadvantages of each alternative based on known properties and past performance. It would be optimal to calculate an expected life cycle cost based on characteristics of the design alternatives and the loads. However, this is difficult because conditions can vary dramatically between locations, making it difficult to estimate loadings and performance. Environmental deterioration of wood, for example, may be a controlling factor in one location and not another. Barge impacts can be location specific; frequency of barge impacts and rubbing contact will vary. Regardless, an alternative must be selected even if a rigorous calculation of cost-benefit is not completed.

\subsubsection{Energy absorption and abrasion}

The primary purpose of fenders is to protect the gate or approach wall structural components. Fenders are intended to absorb energy, but they also provide a rubbing surface as barges pass, so they protect the underlying painted surface and reduce corrosion. Polyethylene provides an excellent rubbing surface. UHMWPE has the lowest coefficient of friction and HDPE would be near two times greater. Steel and rubber would be four times higher than HDPE. Corrosion of steel and deteriorated rubber would tend to increase rubbing friction. 
Wood and steel shapes are known to have energy absorption capacity as they crush and deform, respectively. Damaged wood may only provide minimal protection, but damaged (crushed) steel shapes provide essentially no protection. Polyethylene is generally thought to have less energy absorption capacity than rubber, undamaged wood and steel shapes even though it can also crush and deform. There is clearly a need to distribute loads and absorb energy imparted by barge impacts, but the capacity of these materials and designs to absorb energy and more widely distribute the impact load is difficult to estimate.

While several past studies by USACE have been performed on damage from large impacts by barges causing substantial gate damage where fenders do little or nothing to mitigate, ${ }^{1}$ this investigation found no studies done on smaller impacts to better determine the role of fenders in preventing damage from these events. One of the primary authors of those reports on large impacts (Robert Ebeling, ERDC-ITL) was contacted, and he stated that he was not aware of any studies of relatively small impacts. Subject matter experts in three USACE districts also confirmed that they were not aware of tests of small impacts.

Generally speaking, energy absorption for a particular design can be estimated by testing or dynamic finite element analysis. The Federal Highway Administration has done extensive full-scale crash testing of guardrails, impacting them at various speeds and impact angles ("Public" 2000). Wuttrich, et al. has done dynamic finite element modeling of larger bridge pier fender systems. Neither physical testing nor modeling studies were found for gate fenders.

While no studies were found on the performance capabilities of various fender designs in preventing damage to gates, some testing by vendors of the energy absorption of a few designs was located. Schuyler Companies tested 9x9-in. and 11x11-in. solid rubber fenders (Schuyler brochure) and various loop designs (internal Schuyler report). Trelleborg has done energy absorption testing on cone fenders, cell fenders, leg fenders, and arch fenders (Fender Systems). These fender types are not known to be used on gates. This is likely due to their thickness. Trelleborg also has a design manual (Trelleborg manual) that includes calculations for berthing energy.

\footnotetext{
1 The cited documents (too many to list here parenthetically) are marked with asterisks in the References section ( $p 32$ ).
} 


\subsubsection{Cost}

Wood has the lowest initial cost of the alternatives identified. Oak and Greenheart are more expensive than Douglas fir or various pines. As USACE districts gradually transition to non-wood materials, wood continues to be used most frequently at locations that experience lighter barge traffic. This makes sense in that wood typically has a shorter life expectancy than steel or polyethylene, which can be a significant drawback in high traffic locations where a closure to repair fenders has a high cost to commercial users. Less trafficked locks will likely experience fewer impacts and fewer wetting and drying cycles, which will likely increase the relative life expectancy of wood.

The first cost of steel shapes varies depending on whether the fender is made from a manufactured shape or it is fabricated (see Table 2-1). Manufactured steel shapes tend to be slightly more expensive than wood, but are generally far less expensive than fabricated shapes, polyethylene, and multi-layered designs. Table 2-1 lists some typical approximate costs reported during the survey.

Table 2-1. Some typical approximate costs reported during the survey.

\begin{tabular}{|l|c|}
\hline Fendering type* & Approximate cost per linear foot \\
\hline Wood & $\$ 5-\$ 20$ \\
\hline Steel (structural shapes) & $\$ 20$ \\
\hline Steel (fabricated shapes) & $>\$ 80$ \\
\hline HDPE & $\$ 10-25$ \\
\hline HDPE (with four fiberglass reinforcing rods) & $\$ 25-55$ \\
\hline HDPE (12x12-in. with 4 fiberglass reinforcing rods) & $\$ 60$ \\
\hline UHMWPE (2x12-in.) & $>\$ 70$ \\
\hline Rubber (EPDM) & $\$ 90-120$ \\
\hline Layered (UHMWPE, rubber, steel shape) & $>\$ 100$ \\
\hline Layered (UHMWPE, rubber) & $>\$ 100$ \\
\hline $\begin{array}{l}\text { * Notes: } \\
\text { Unless otherwise stated, shapes are roughly8x8-in. } \\
\text { Listed prices do not indude installation. Yellowtinted PE can cost twice as much as black PE. }\end{array}$ \\
\hline
\end{tabular}




\subsubsection{Environment}

Wood is very susceptible to environment related degradation, especially in the wet but un-submerged applications typical for fenders (Figure 2-14). The various preservatives that are used to slow the degradation also have disadvantages and tend to lose effectiveness with age. Moreover, the chemicals used to treat wood such as TreCreosote and chromated copper arsenate can leach from the wood into the water, and can harm the environment. Depending on local regulations, wood treated with these chemicals may need to be discarded as hazardous waste.

Anecdotal reports of expected life from various USACE districts indicate that wood may last longer in northern climates. Indeed, it has been reported that temperatures of 70 to $85^{\circ} \mathrm{F}$ are optimal for fungi growth (a primary cause of wood decay [Lindgren 1953]). These temperatures are less common in northern climates. The higher temperatures also increase ultraviolet (UV) related degradation. However, these factors are somewhat mitigated by less freeze damage in warmer climates.

Figure 2-14. Deteriorated wood fenders and one replacement HDPE fender.

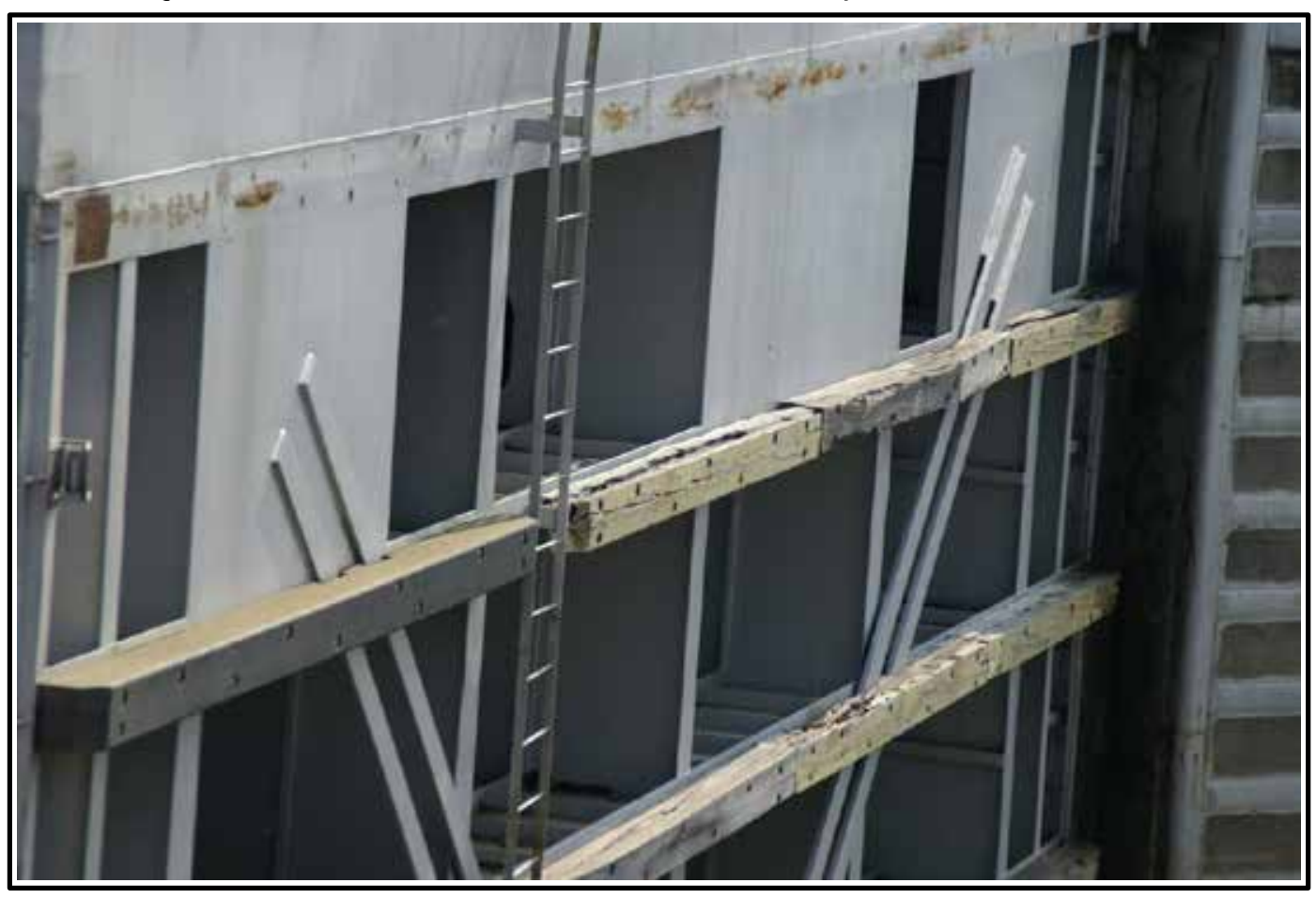


Most materials are affected by UV. Rubber, neoprene, and plastics can be made more UV-resistant through the addition of pigmentation and UV inhibitors. Most commercial vendors include additives for UV protection. Note that these materials generally compose large cross-section members such that UV damage will mostly be limited to the surface. UV may be an important concern in some circumstances, but it was not investigated for this report.

\subsubsection{Durability (impact and rubbing)}

Wood tends to be the least durable fender material. It is common for barge contact to crush wood fenders. Barge contact also causes steel shapes to deform and essentially to lose all protective capability. Polyethylene and layered materials provide the most durable solution. Multiple survey respondents indicated that polyethylene performs excellently under rubbing forces, and that it can also sustain higher impact loads without permanent damage. The principal drawback of polyethylene is that it has lower energy absorption than wood or steel. Other concerns, which are also associated with wood and steel shapes, include broken bolts and catching corners. Kentucky Lock has an approach that frequently leads to barge impacts on the upstream wall (Figure 2-15). The HDPE timbers have proven more resistant to damage than wood timbers.

Figure 2-15. Kentucky Lock upstream approach wall with yellow fenders for better visibility.

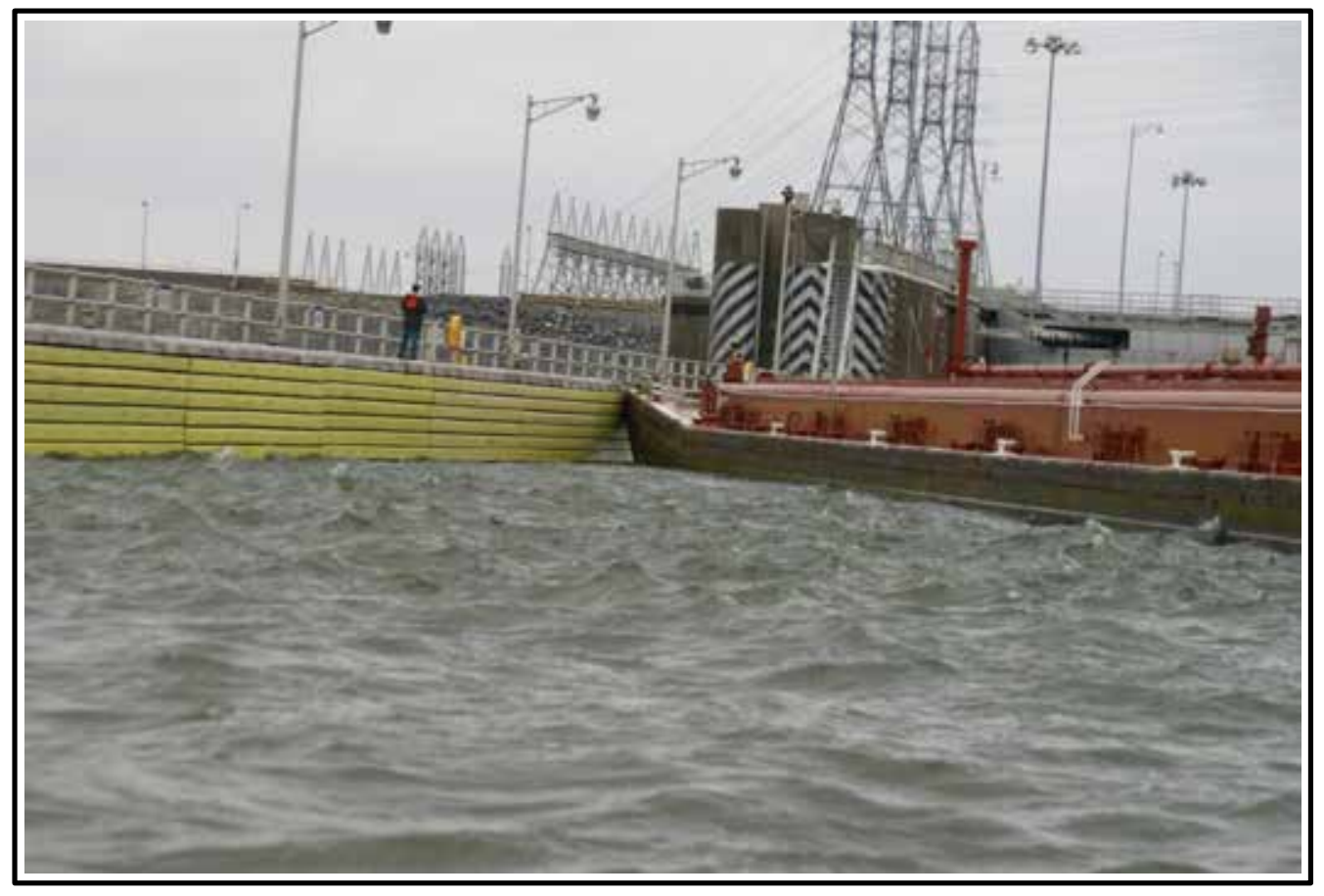


Appendix B includes additional photos of UHMWPE-rubber fenders damaged by barge impact at Greenup Locks and Dam.

\subsubsection{Bolts and attachments}

Many USACE districts reported problems with the attachment of polyethylene timbers due to bolt pull-out and breakage. Countersunk bolts increase this risk, especially for HDPE, which has a relatively less dense core (Figure 2-16). The bolt breakage issue may be similar for wood except that, since polyethylene can otherwise survive greater forces, pulled through or broken bolts are more likely to appear as the sole failure mode.

Slotted bolt holes to allow differential thermal expansion also decrease the resistance to bolt pull-out. One USACE district reported no issues with polyethylene timber bolted attachments. They did not slot their bolt holes for expansion. It is not clear why this worked successfully, given the difference between thermal expansion of the polyethylene and steel, but they reported no problems. There may have been relatively short timbers with numerous bolts and infrequent barge impact or a climate where the temperature range is relatively small.

A different attachment method has been successfully used on the approach walls at the Emsworth Locks \& Dams, Pittsburgh, PA (Figure 2-17). More recently, it was learned that a similar attachment was used for fenders on the miter gates at Lockport Lock and Dam, Lockport, IL (Figure 2-18). The vertical through-bolts used in these two applications should eliminate most problems with weak attachment while also allowing expansion slots as large as necessary. The Lockport application also addresses creep by fully supporting the member with a steel channel. Soo Locks use a similar attachment with oak fenders. 
Figure 2-16. HDPE timbers with circular less dense and softer core.

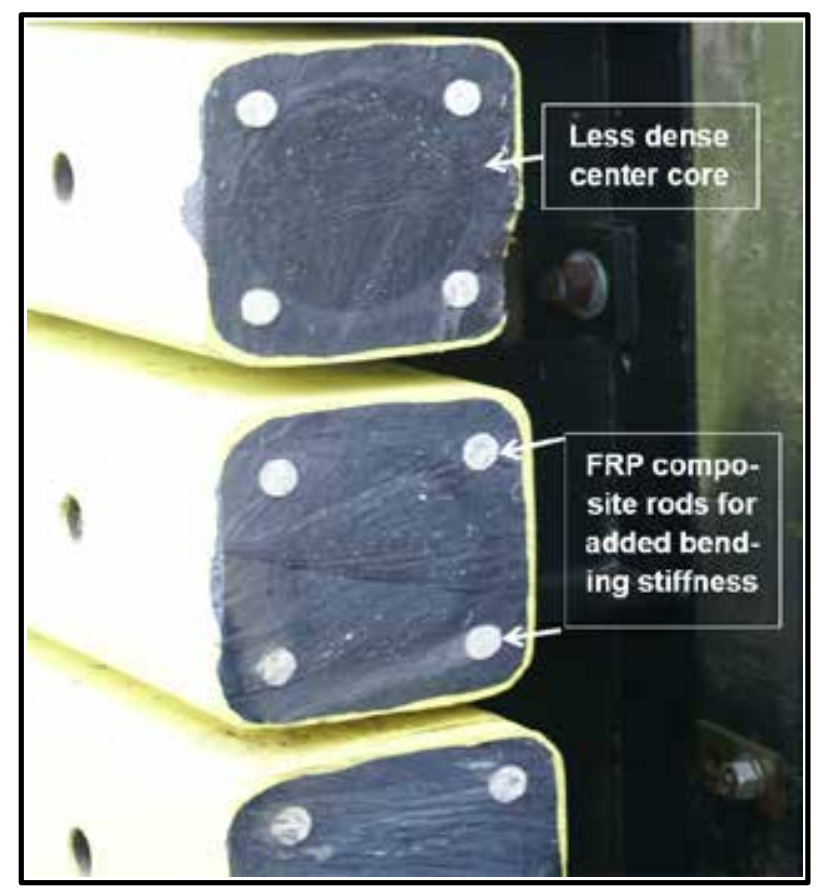

Figure 2-17. Approach walls at the Emsworth Locks \& Dams, Pittsburgh, PA

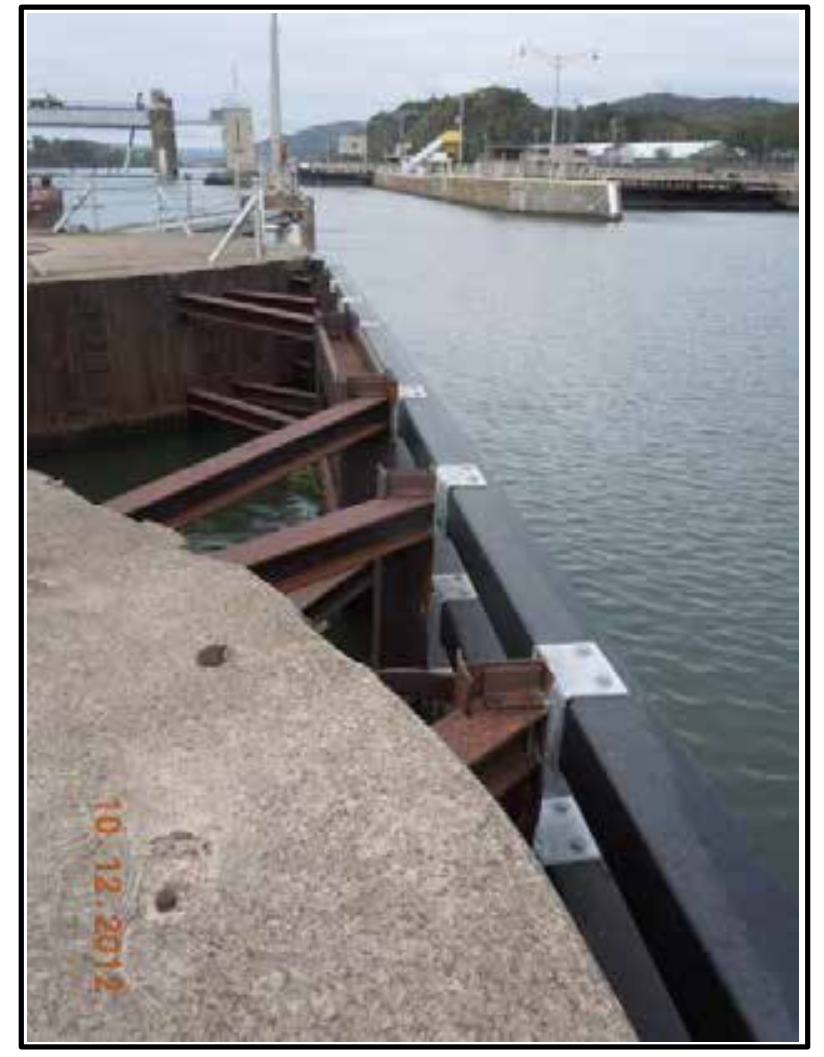


Figure 2-18. Fenders at Lockport Lock and Dam, Lockport, IL

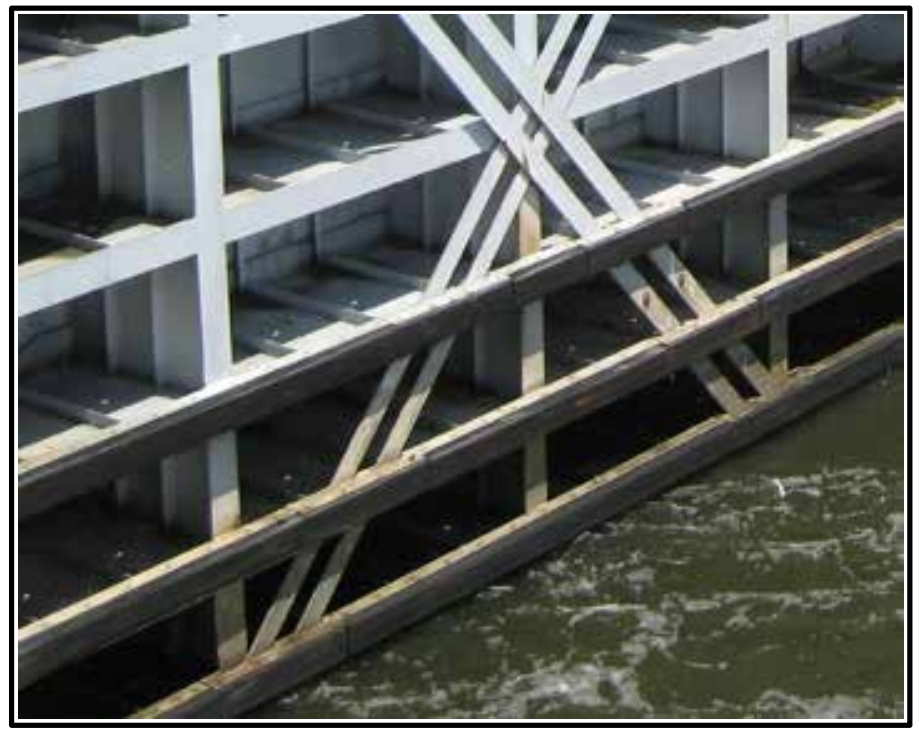

\subsubsection{Termination design}

Fenders separate the barge from the gate, thereby limiting the potential for hang-ups on corners that might transfer more load as the barge passes. While a hang-up on a fender will cause far less damage than a hang-up on a gate structural member, the ends of the fenders are a common point of damage. If a barge hits just before the fender, it may not slide past the start of the fender; or as it slides by something, the barge may get snagged as it passes the endpoint of the fender (see Figure 2-19). Some fenders are tapered to reduce the likelihood of hang-ups but a tapered fender also provides less protection to the underlying gate.

Figure 2-19. View of typical plate deformation and broken weld at the fender guard transition (Greenup L\&D).

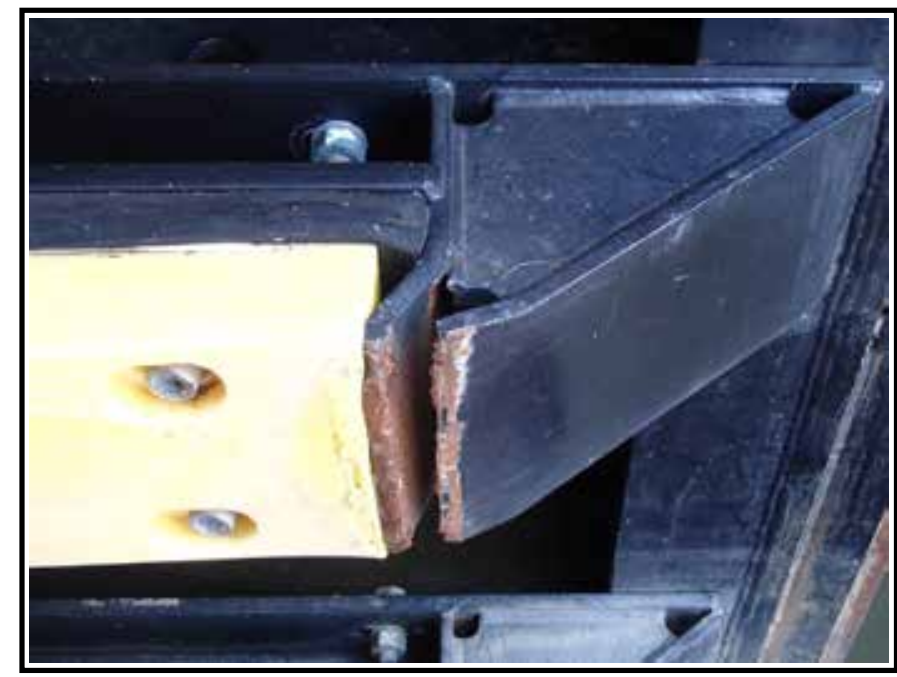




\subsubsection{Installation and removal}

If a fender is destroyed, quick access to purchase materials and the ease with which those materials can be stockpiled can be important considerations. Ease of removal and replacement can impact the length of closure for installation. The location of available attachment points can also be important. Note that these installation and removal issues, which can be important factors, were not investigated for this report.

\subsubsection{Creep}

Polyethylene has a tendency to creep and sag over time. The longer the unsupported length and higher the service temperature, the more this becomes an issue. The use of glass fiber reinforcement or fiberglass composite rods (Figure 2-20) adds stiffness and provides added resistance to creep by reducing the strain in the HDPE. The added cost needs to be weighed against the cost of alternatives such as the use of additional supports for the fenders.

Figure 2-20. Composite rebar reinforced HDPE timbers. Note yellow color throughout the cross-section.

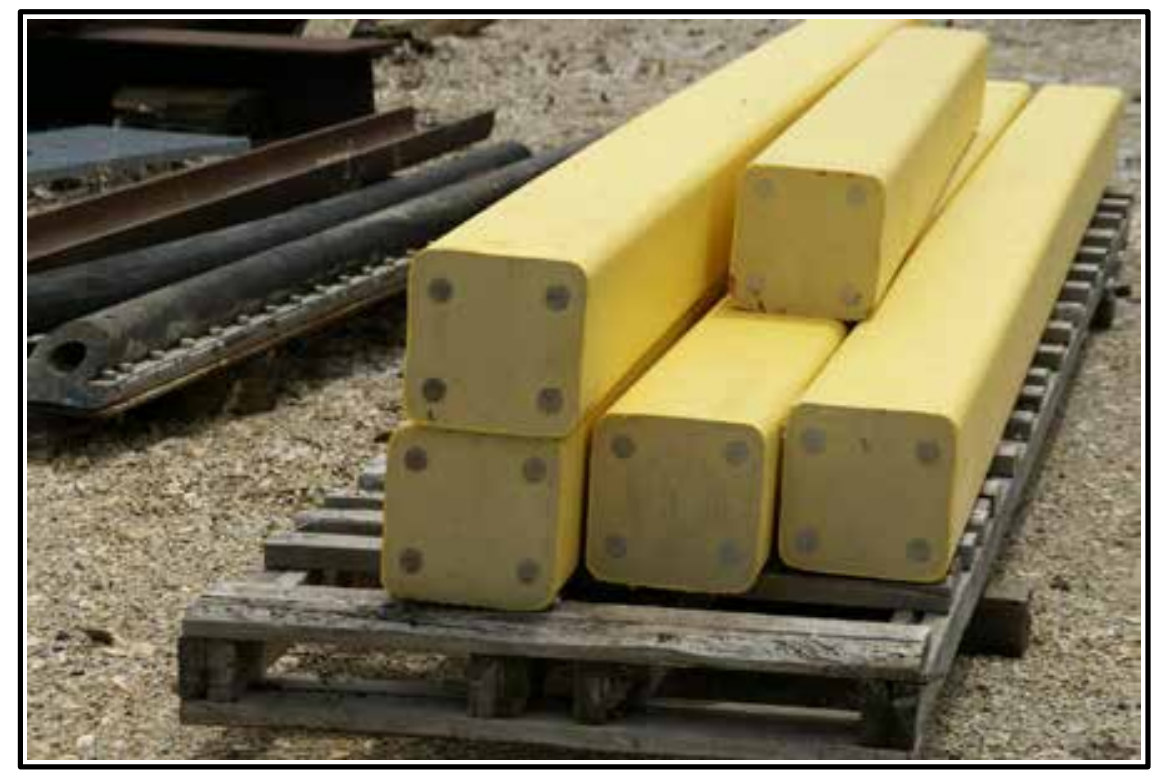

\subsubsection{Review of advantages and disadvantages}

The data in Table 2-2 summarize the advantages and disadvantages of wood and the alternative fender types based on information gathered. 


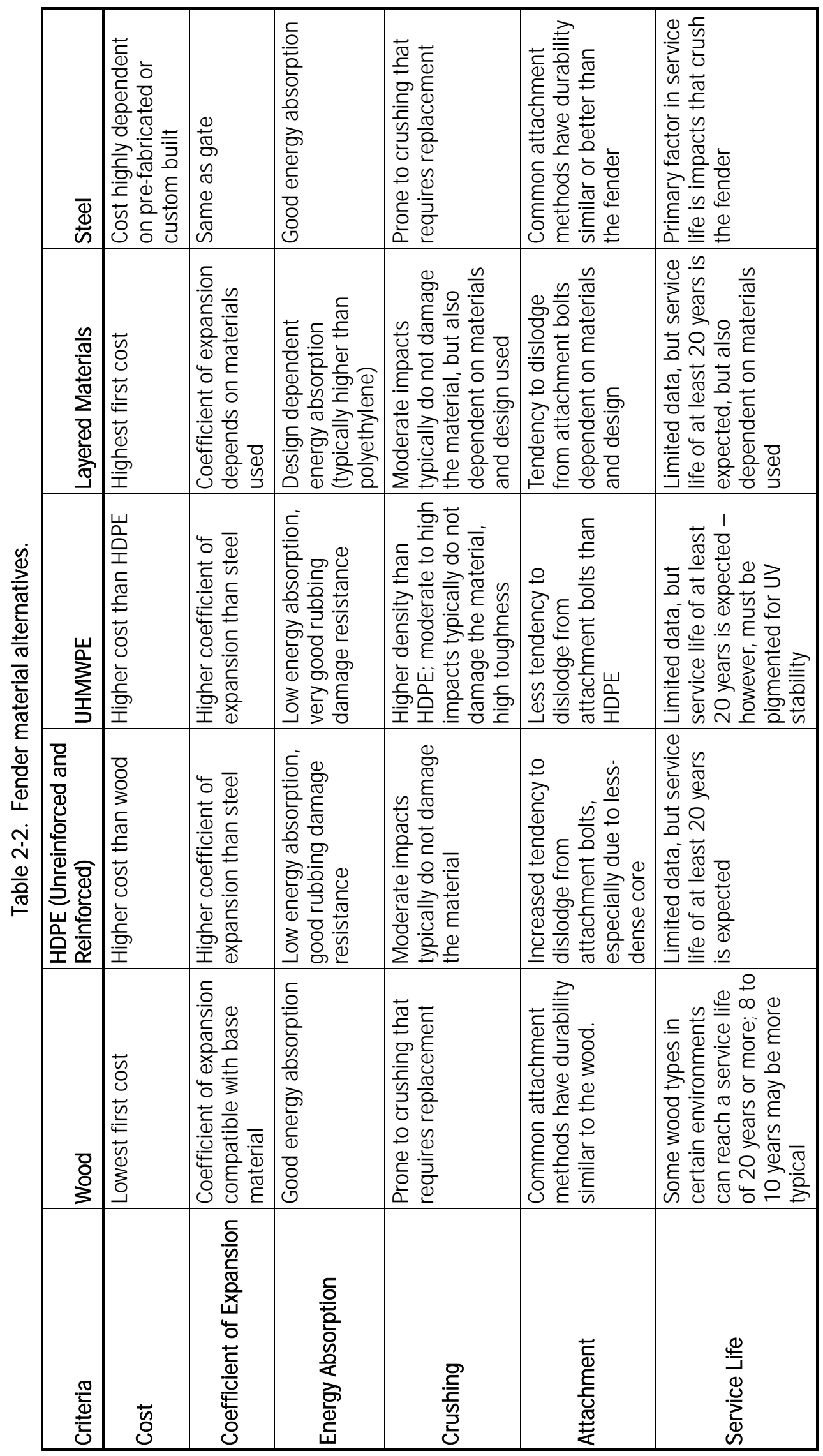




\begin{tabular}{|c|c|c|c|c|}
\hline $\begin{array}{l}\bar{\Phi} \\
\text { ث્" }\end{array}$ & 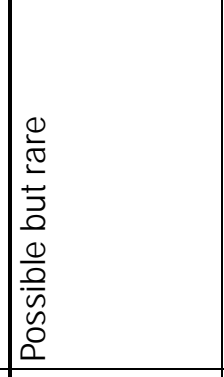 & 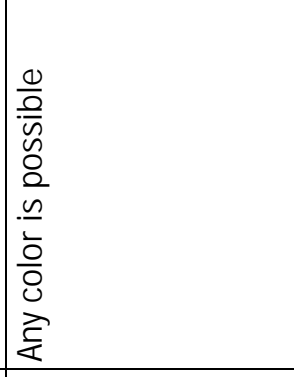 & 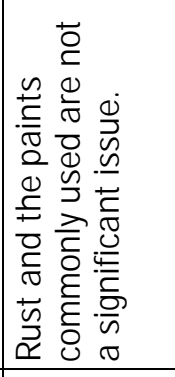 & 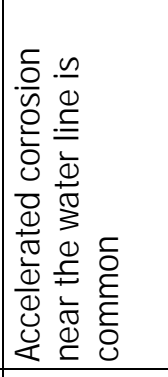 \\
\hline 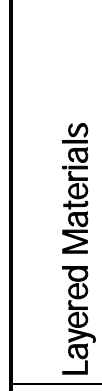 & 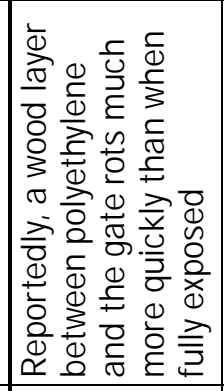 & 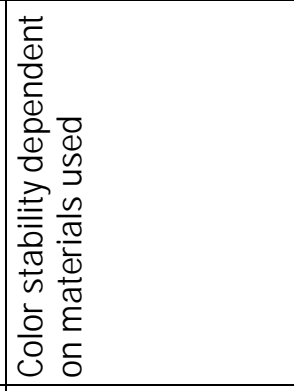 & 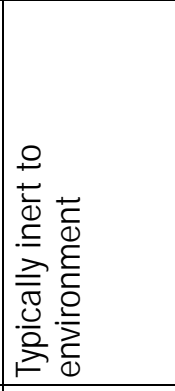 & 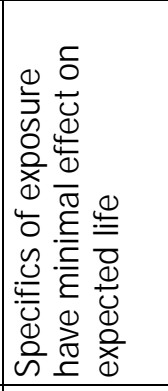 \\
\hline 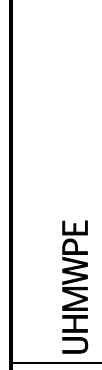 & 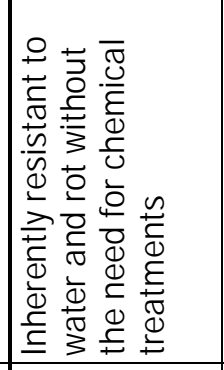 & 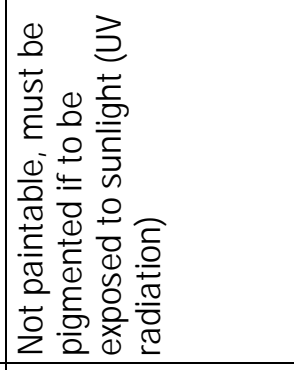 & 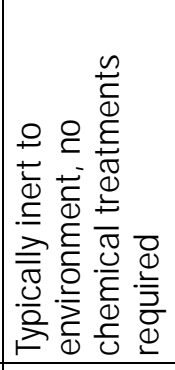 & 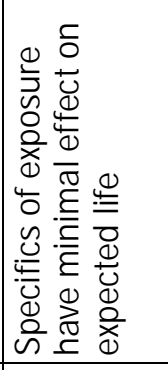 \\
\hline 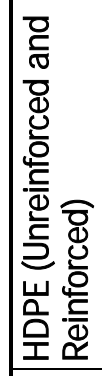 & 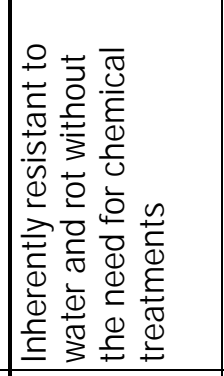 & 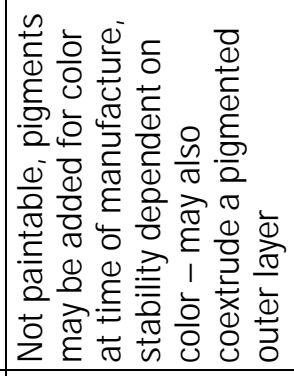 & 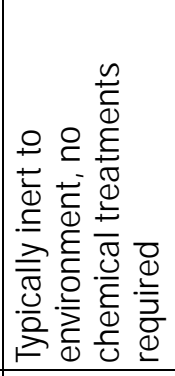 & 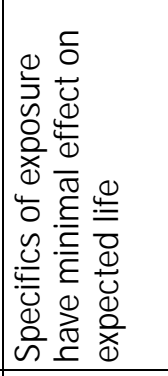 \\
\hline 8 & 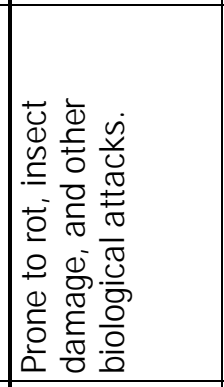 & 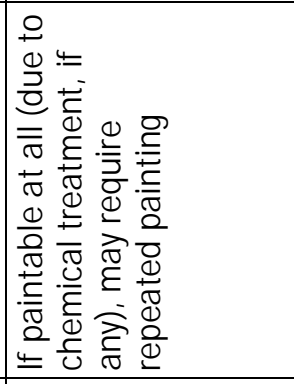 & 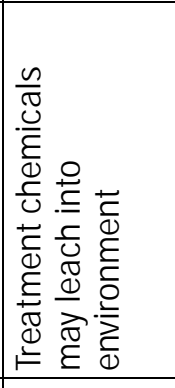 & 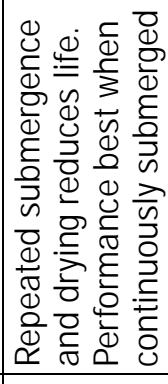 \\
\hline 焉 & $\begin{array}{l}.0 \\
\frac{0}{0} \\
0 \\
\frac{8}{8} \\
0 \\
.0 \\
\frac{0}{7} \\
8 \\
0\end{array}$ & $\begin{array}{l}\frac{.}{\overline{0}} \\
\frac{\alpha}{0} \\
\frac{0}{0} \\
\frac{0}{0} \\
\frac{0}{3}\end{array}$ & 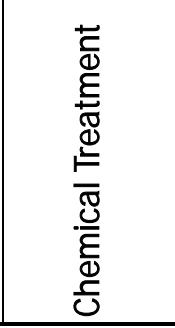 & 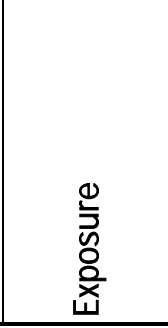 \\
\hline
\end{tabular}




\subsubsection{Louisville District best practices survey}

As part of a selection process for new fenders, Louisville District contacted other districts. Appendix C includes a summary of their survey results. These results, shown as notes, include recommendations, common problems, and preferences for materials and designs.

\subsection{Common field usage guidance for plastic-based lumber and timbers}

Optimal performance of bumpers also depends on the appropriate use of materials and consideration of material properties during the installation process. When using plastic-based lumber:

- It is recommended to pre-drill holes (see Figure 2-21).

- Carbide-tipped blades and bits are recommended.

- Do not drill holes near any embedded rebar material as the load capacity will be altered if the rebar is damaged.

- Rip cutting is not recommended on HDPE since it exposes the weaker core and may also lead to warpage. Warpage can vary depending on the size and manufacturing process used. Depending on the application, adding fasteners, as needed, can minimize the warpage.

- Before installation, store products on a flat, level surface (or on closely spaced supports to reduce the possibility of creep deformation).

- Allow product to adjust to the surrounding temperature before installation; avoid placing the timber in unusually hot areas (e.g., direct sunlight) directly before installation.

- Slotted bolt holes lead to more frequent bolt pull-through. Not slotting holes for differential temperature expansion can shear bolts in unslotted holes, especially ultra-high molecular weight (UHMW) polyethylene, which has a higher coefficient of thermal expansion than HDPE. 
Figure 2-21. Predrilling the attachment points.

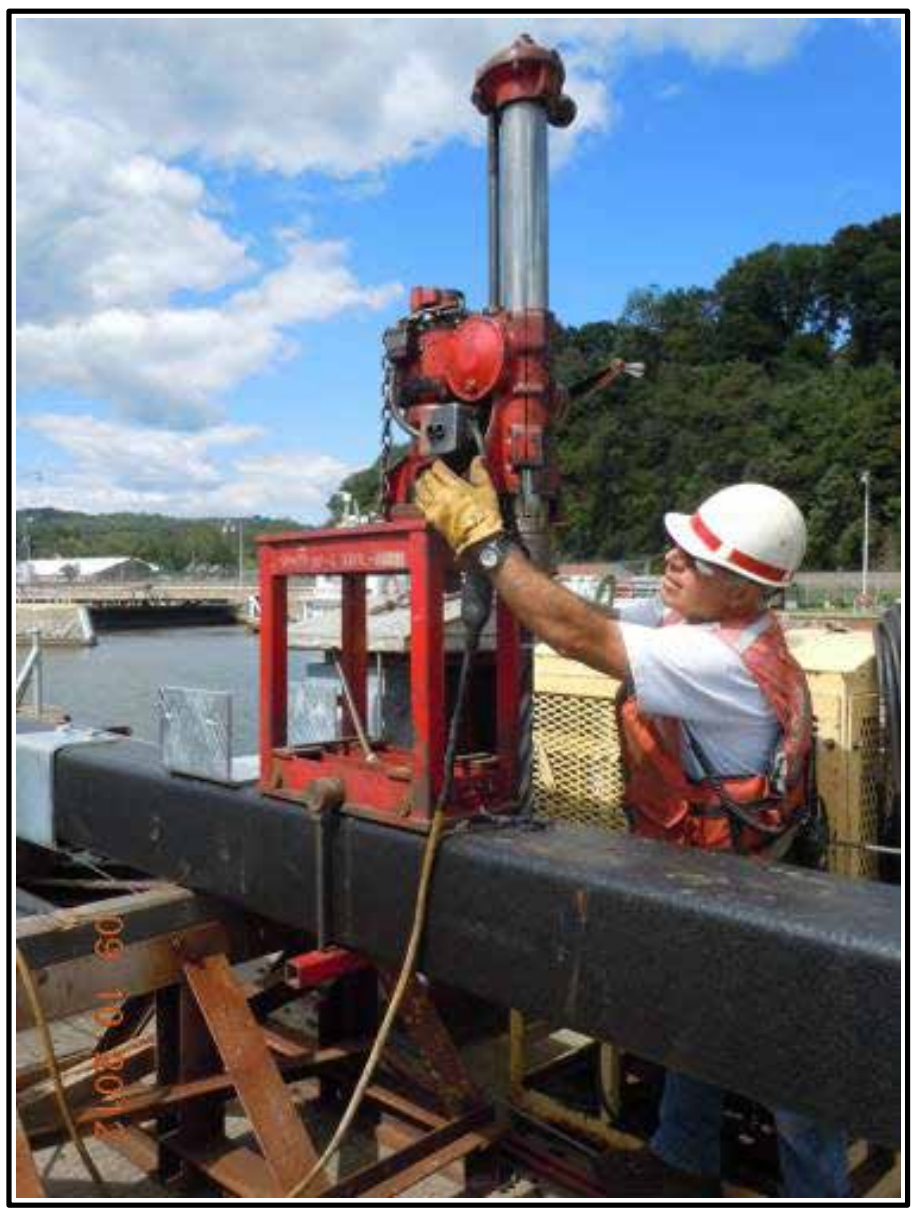




\section{Summary}

\subsection{Conclusions}

Wood, steel, polyethylene, rubber, and composite fenders of various types have their advantages and disadvantages. Certain applications are more likely to favor one over the other, but in general, the optimal material for a given application may vary from location to location, and at some locations, it may be difficult to be certain which alternative will be optimal.

Selection of the fender material and design for a particular location and application may be driven by first cost, the need to minimize the frequency of fender damage and repair, or on other sole criteria. Multiple factors should be considered when selecting an appropriate fender design. They include: frequency of traffic and approach conditions, which are the primary factors in determining historical frequency and severity of barge impacts; the material's ability to survive impact(s); the material's ability to protect the gate; regional material availability; weather at the location; weather resistance of the fender material; frequency and duration of closure for fender-related repairs; and labor costs. Aesthetics, differences in maintenance, and other factors may also need to be considered. Ultimately, all of these factors should be considered in a life-cycle cost estimate, which could vary from a subjective estimate based on what has historically worked at that location to a data-driven estimate of costs that includes durability probabilities and consequences.

\subsection{Recommendations}

While it is hoped that this report provides useful information, it was a relatively small effort to summarize readily available information. There are numerous issues it addresses minimally or not at all. Some issues for possible further investigation include the following:

- USACE does not have an inventory of the types of fenders that are used. This would be useful information. Statistics on life and reasons for repair and replacement could also be useful.

- The energy absorption capability of different materials and designs and their ability to protect gates is not known quantitatively. The relative importance of energy absorption versus load distribution has not been quantified and is not well understood. Although individuals have better knowledge than others, this information is very difficult to pass on to 
others with greater details than "Based on my experience, I think A is better than B." Physical testing similar to that performed by Schuyler and Trelleborg for port fenders as well as computational analysis could be performed to measure and quantify energy absorption and load redistribution capabilities.

- The effort described in this report did not include an investigation of the duration and frequency of repairs and replacement of alternative materials and designs. Lock closures can result in monetary losses to the users that are far larger than installation and maintenance costs.

- While this report describes some causes of environmental damage, further investigation in this area could be done.

- This report also discussed some less common fenders designs. It is likely there are others that were not discovered. Similarly, it is possible that further research of alternative designs could result in new designs that better meet the factors listed in Section 3.1.

- The ends of fenders are common points for snags on barges and other impacts that damage the fender. Design improvements, including tapering, could yield especially large benefits in this area.

- While this report includes some discussion of the differing performance of wood depending on environment, there are many variable that are not well understood or unknown. Differences in wood types and treatment methods are some of the variables that may affect performance, and that may require further investigation. 


\section{Appendix A: Additional Photographs of Miter Gate and Guidewall Fenders}

Figures A-1 to A- 12 show additional examples of miter gate and guidewall fenders as used on Corps of Engineers structures.

Figure A1. HDPE fenders.

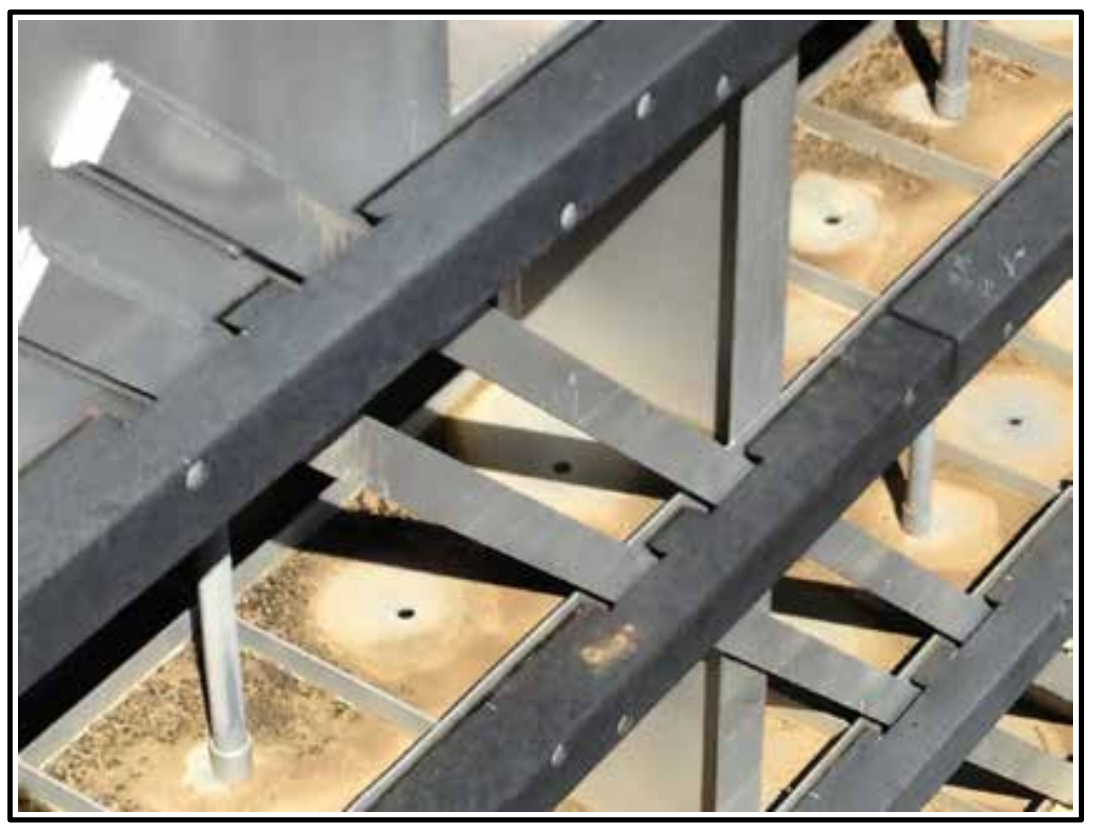

Figure A2. Installation of HDPE fenders colored yellow for visibility.

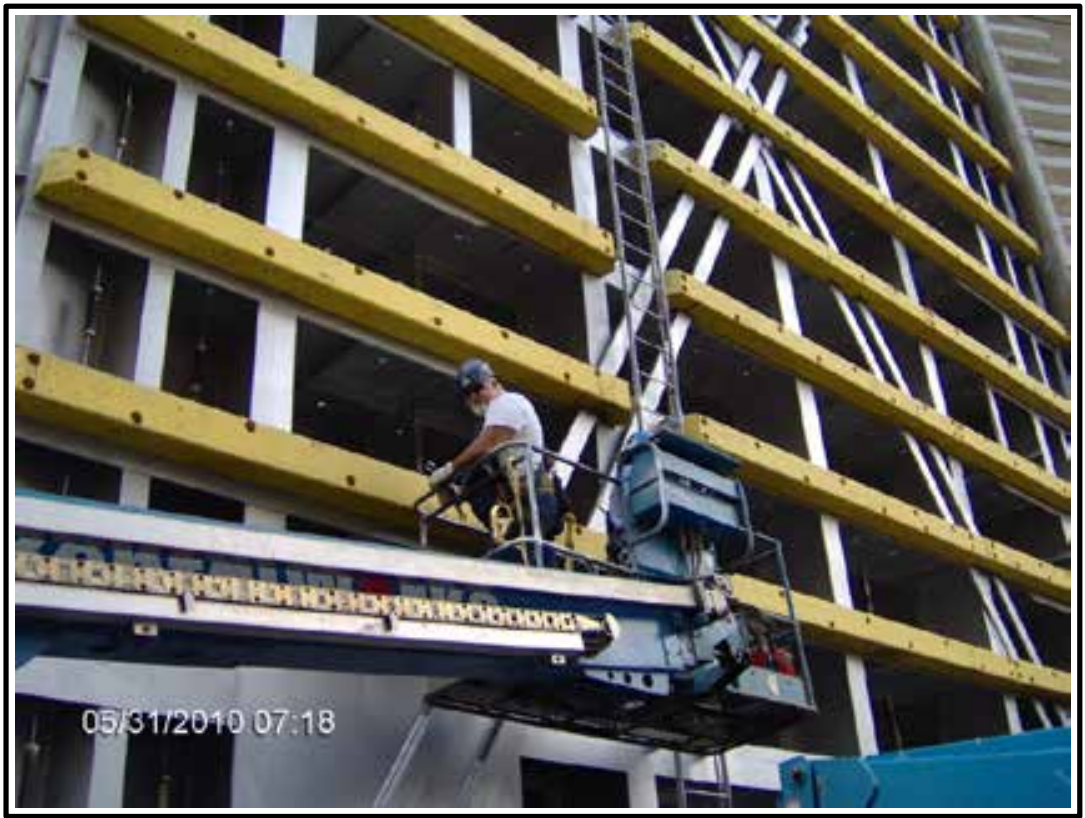


Figure A3. Fender repairs. Notice vegetation growing out of the timber.

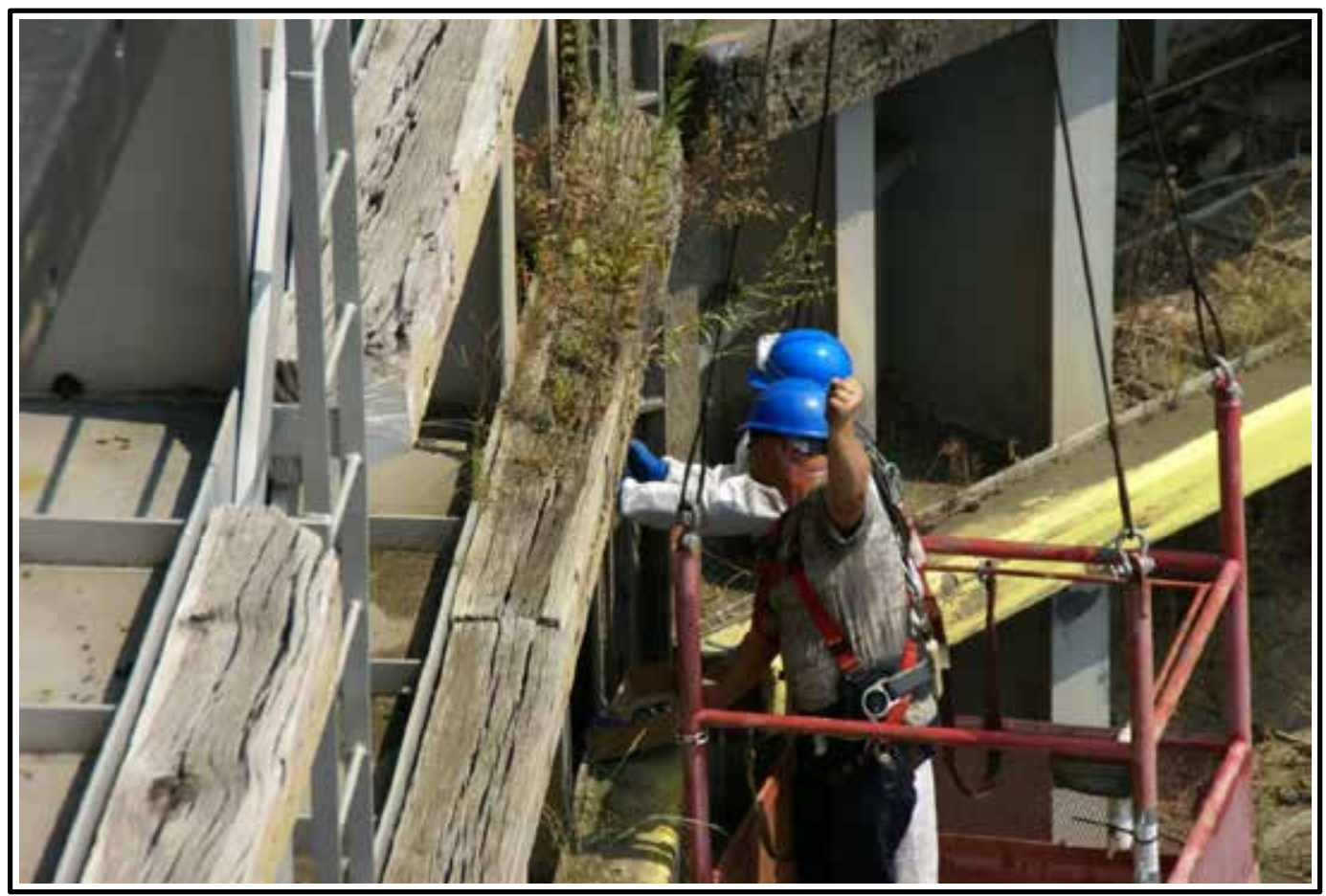

Figure A4. Various fender types and damaged ladders.

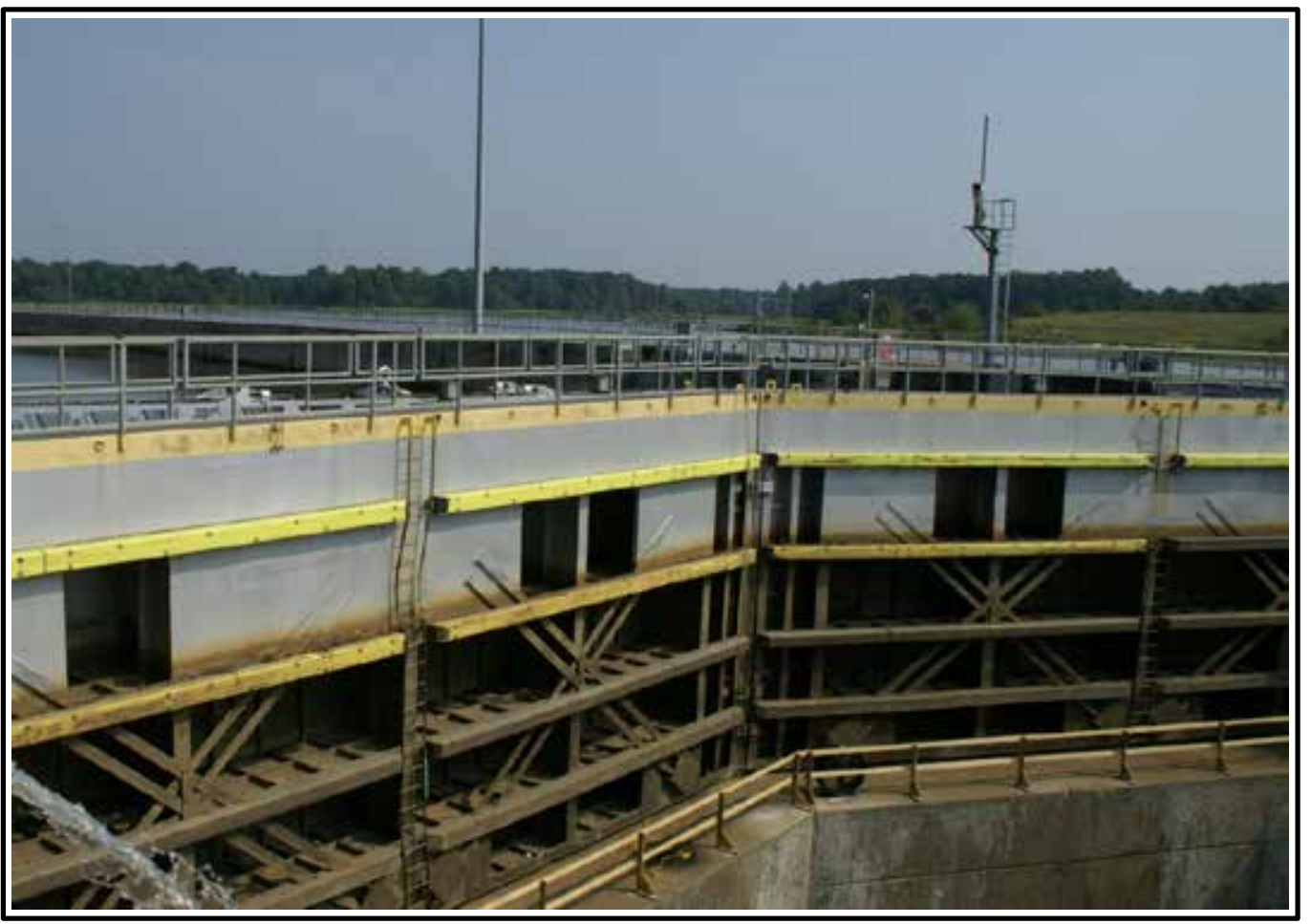


Figure A5. Various fender types and damaged ladder.

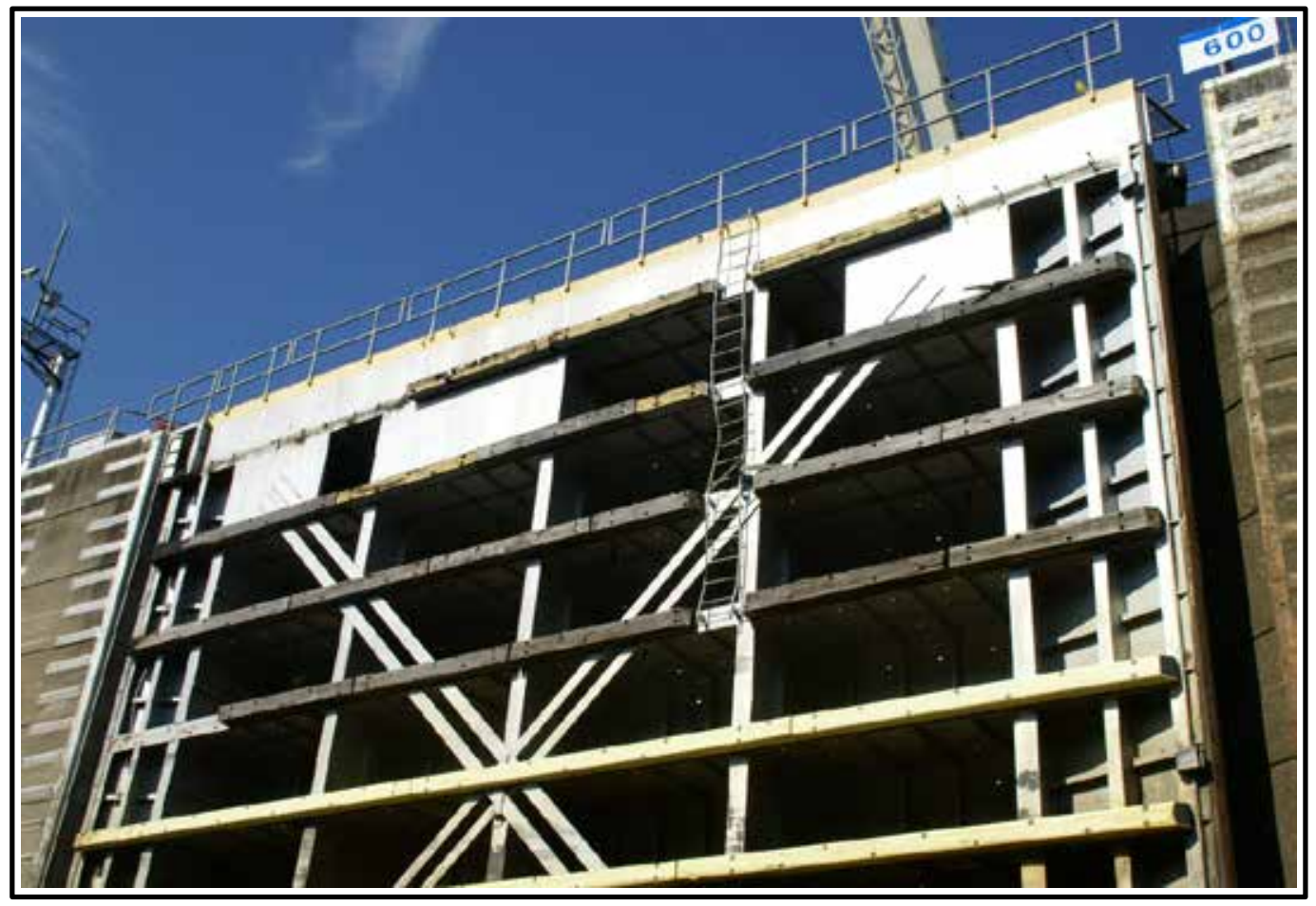

Figure A6. Approach wall with yellow HDPE fenders (Kentucky Lock).

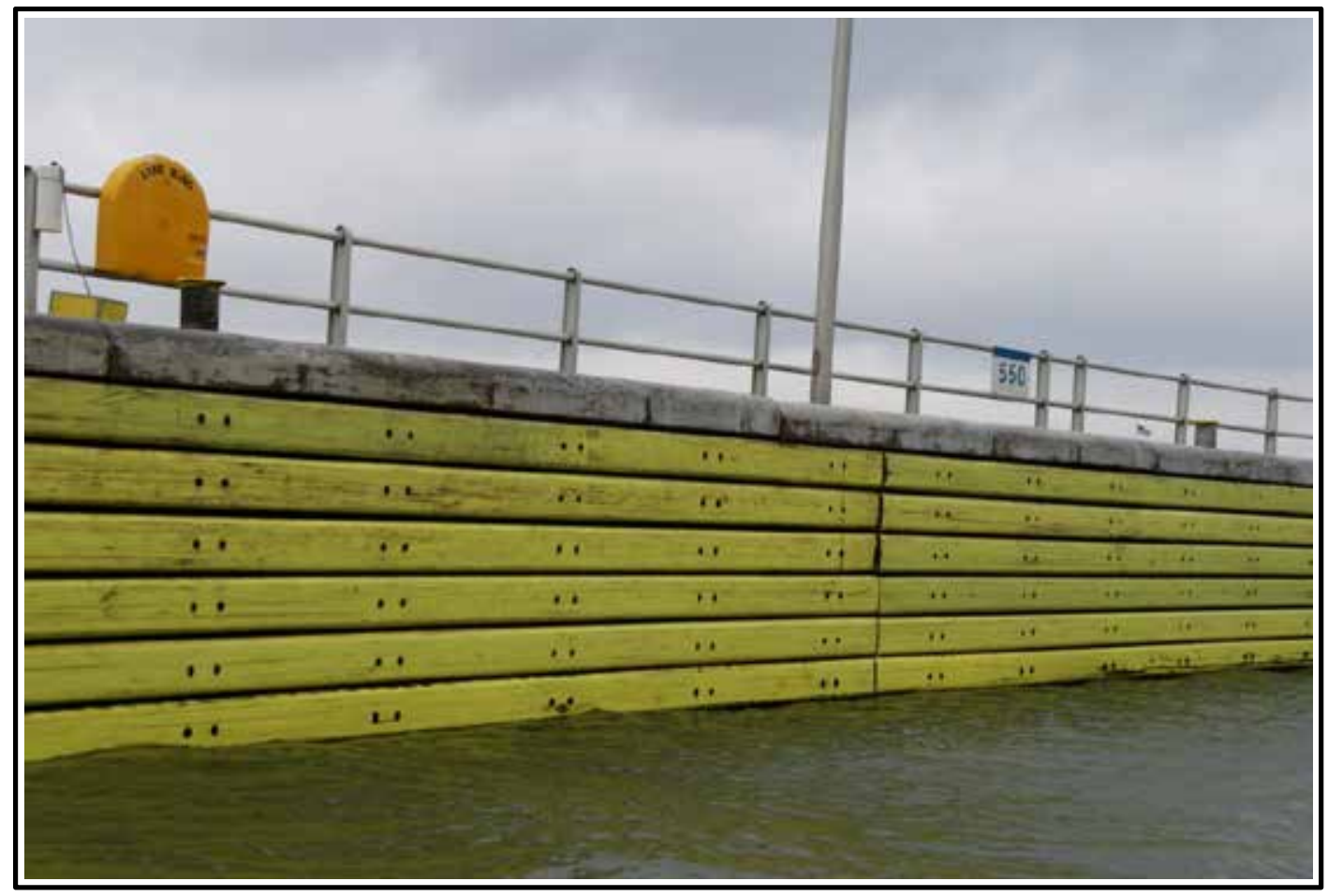


Figure A7. Approach wall with HDPE fenders (Lake Borgne Surge Barier).

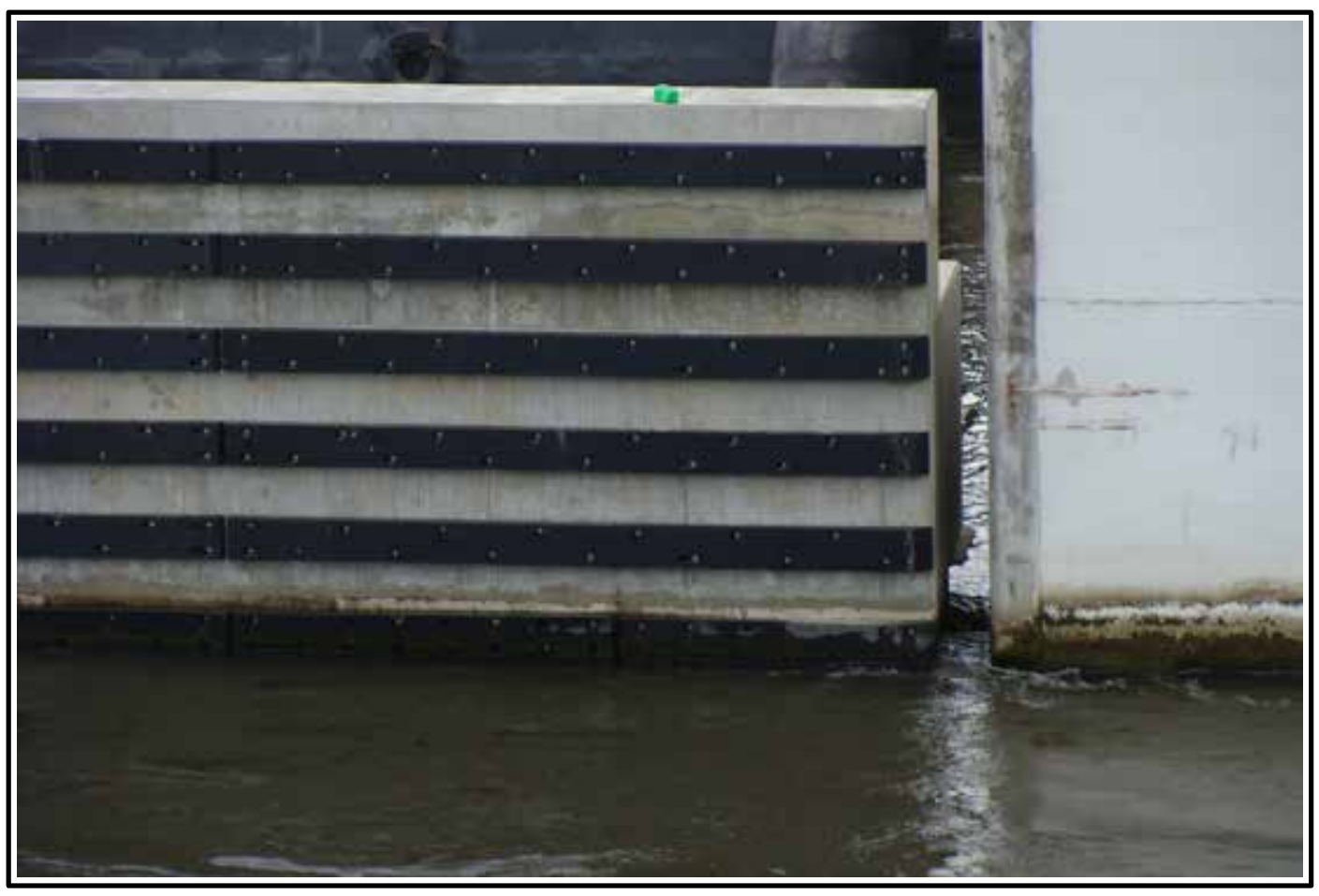

Figure A8. Guidewall with HDPE fenders (Port Canaveral Locks).

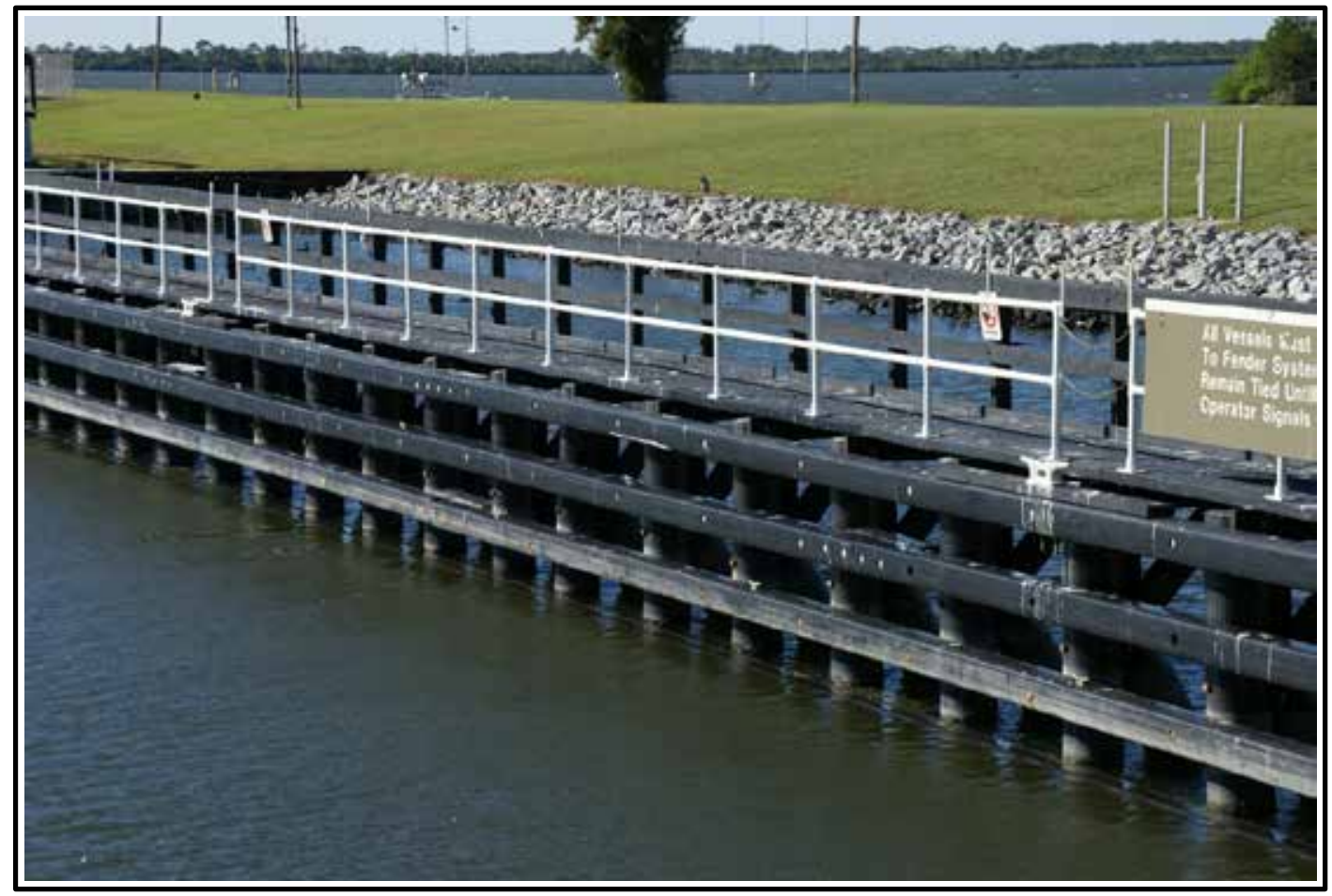


Figure A9. Composite plastic bumper with polyethylene core and FRP reinforcement.

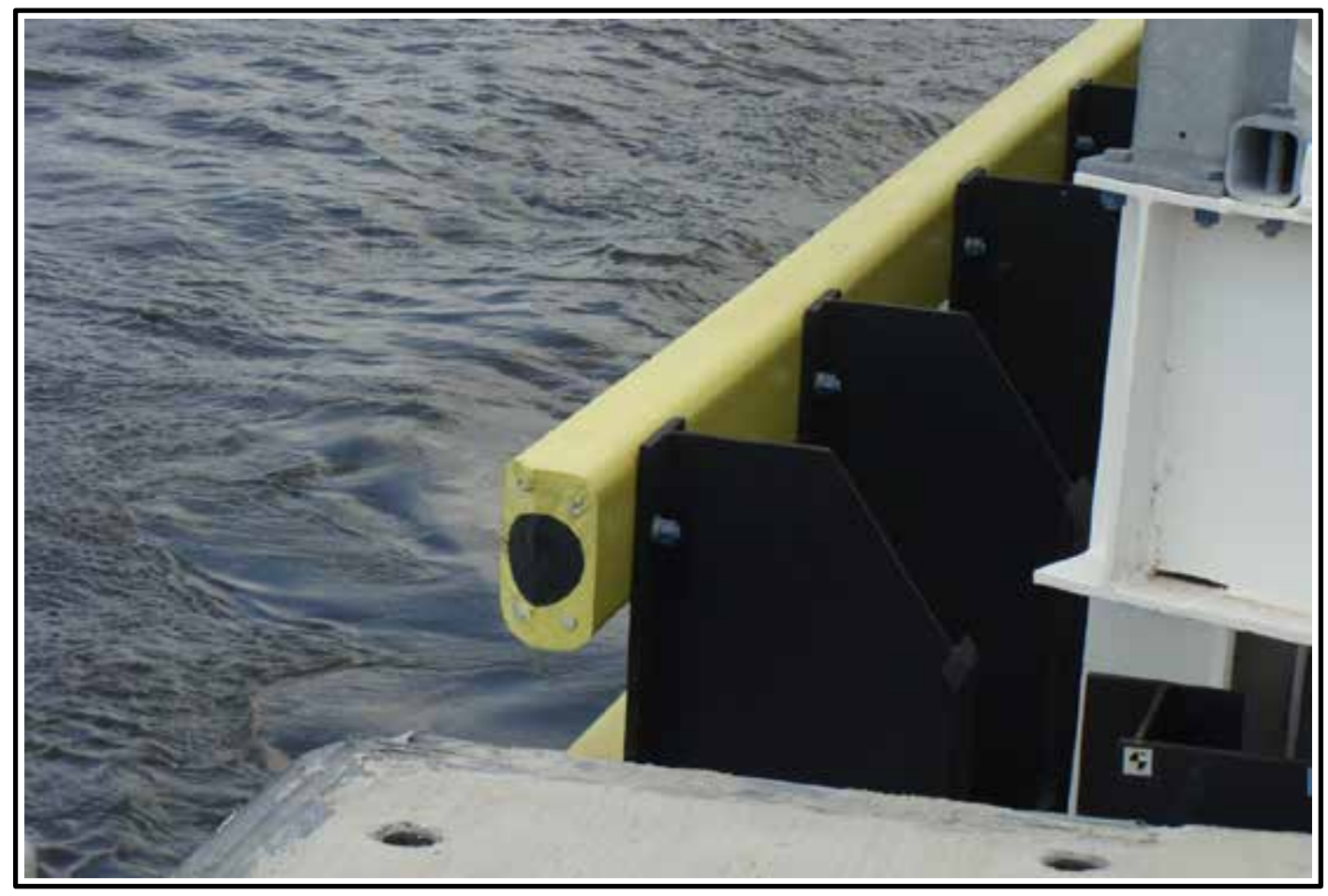

Figure A10. Deteriorated wall due to barge rubbing (Ohio River Lock \#52).

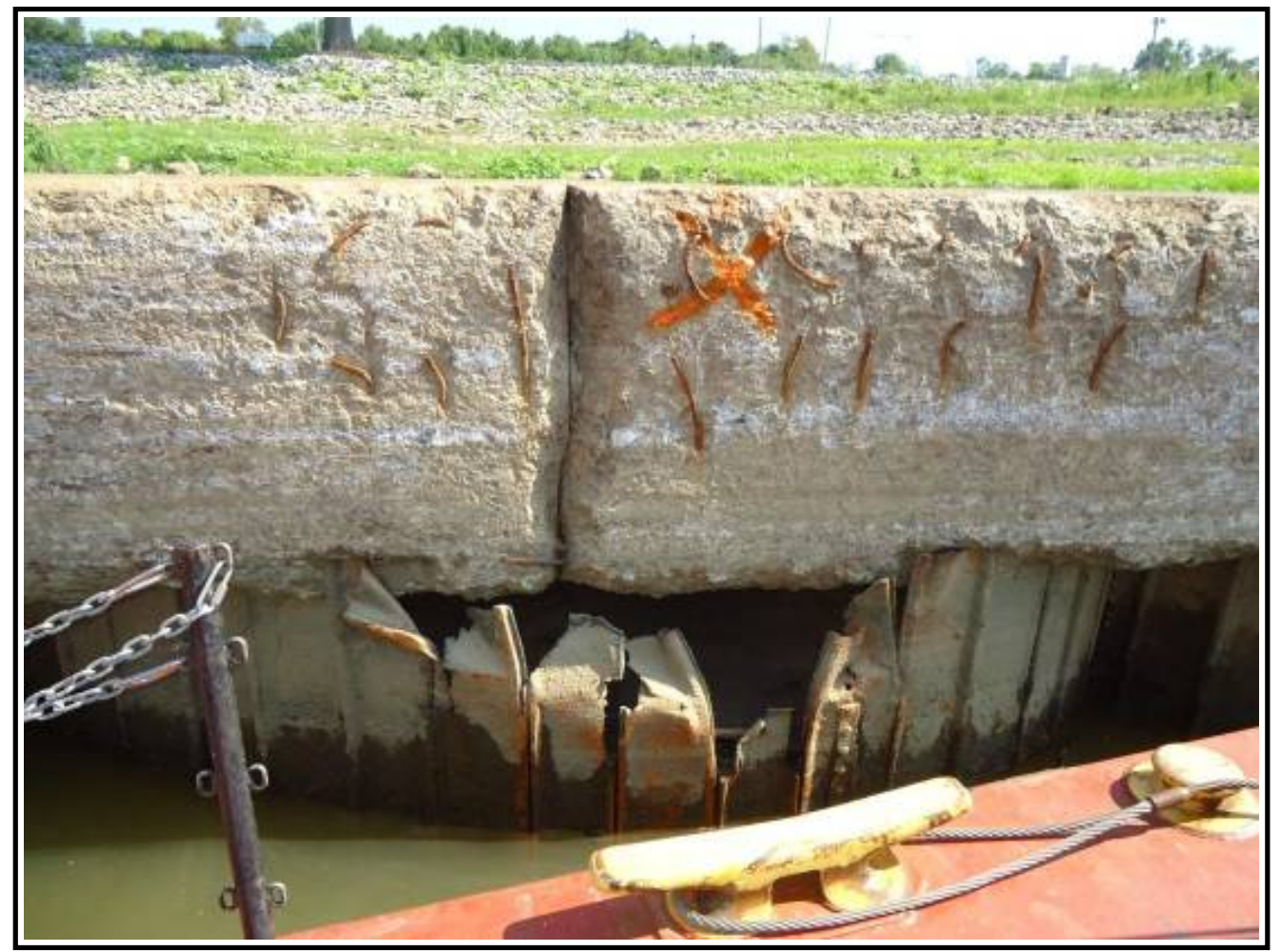


Figure A11. UHMWPE panel on deteriorated armor wall (Ohio River Lock \#52).

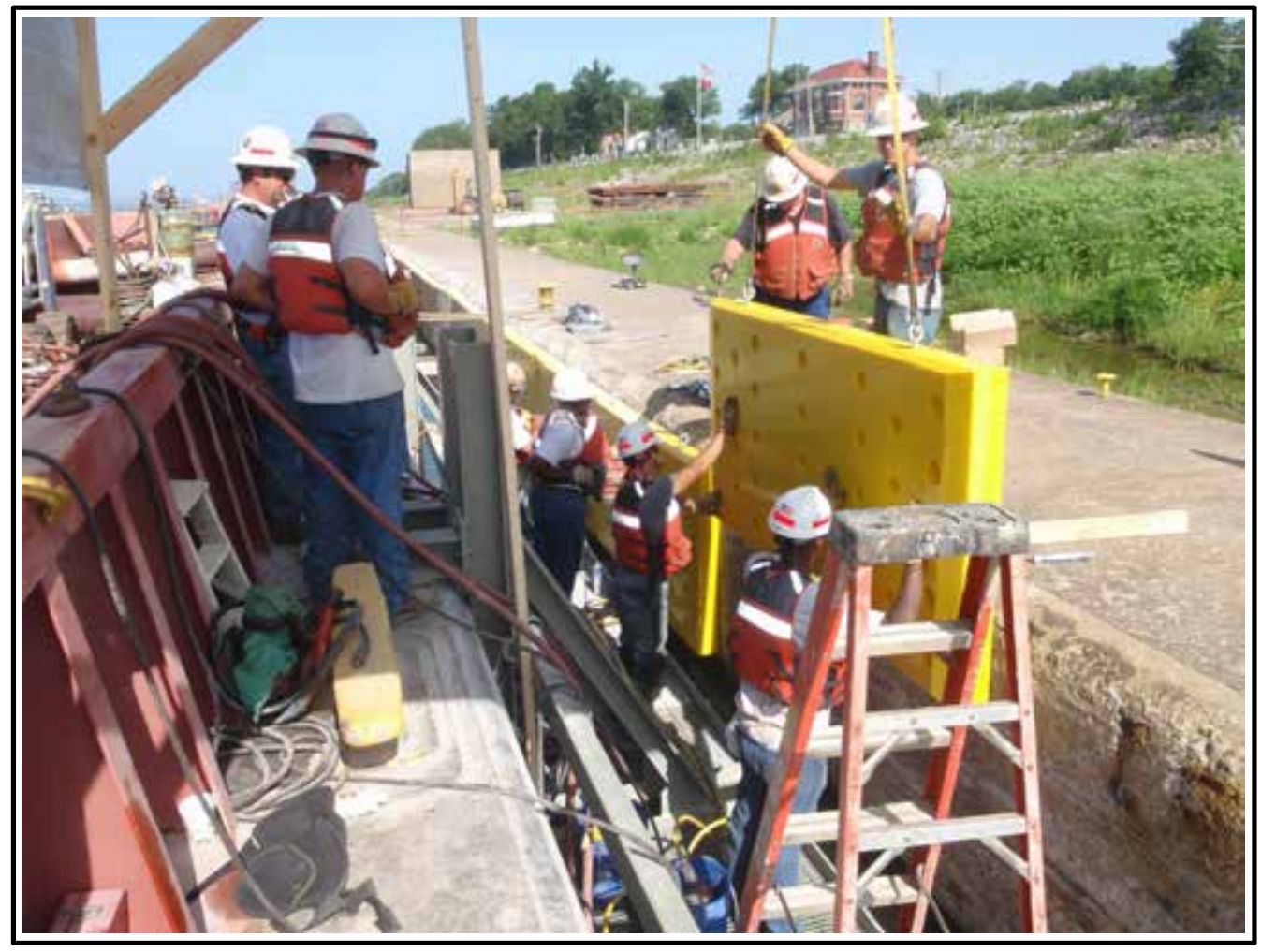

Figure A12. HDPE timber with typical void formations in the center core.

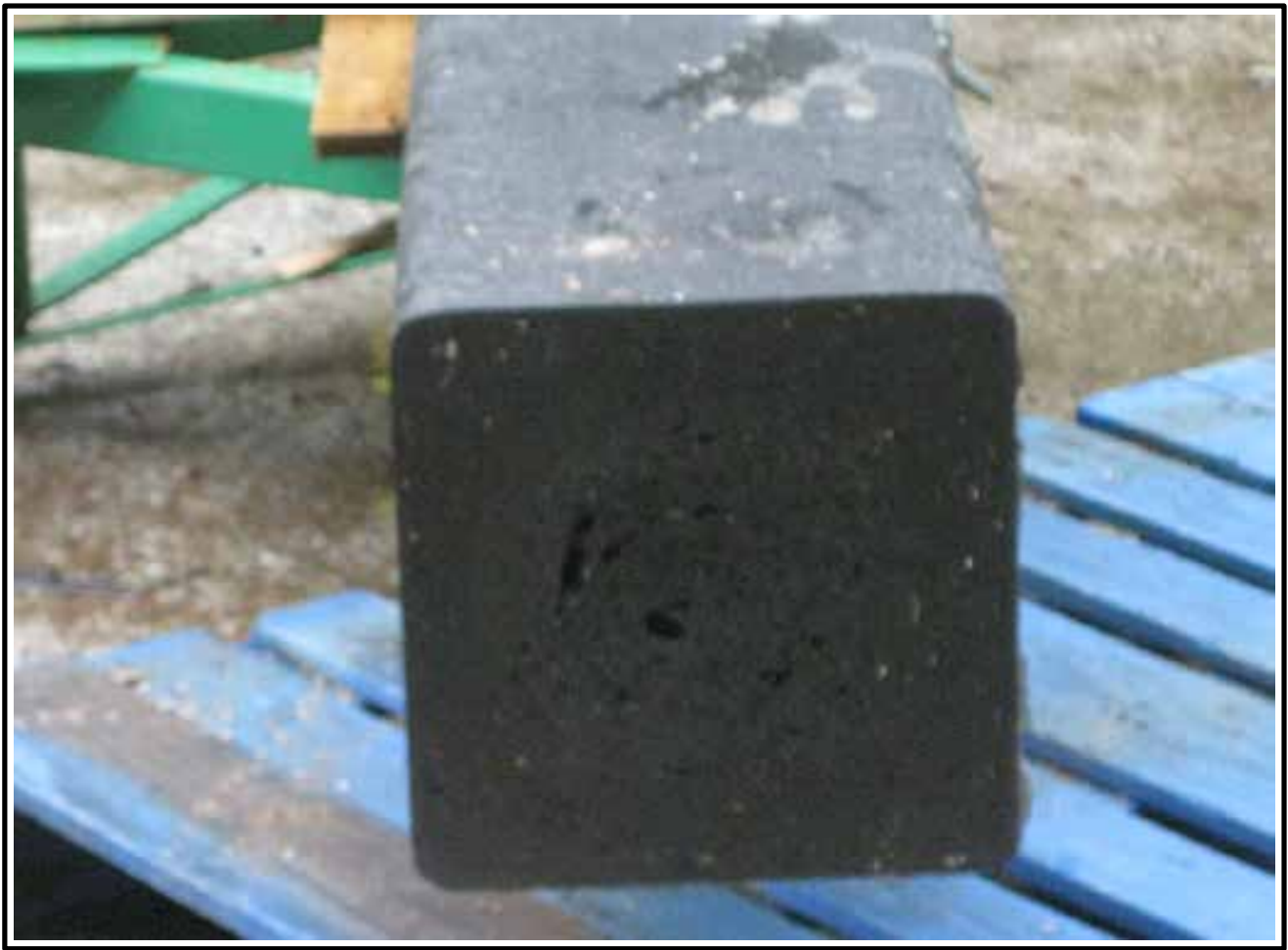




\section{Appendix B: Photographs of Damaged Fend- ers at Greenup L\&D}

In early J une 2014, a barge impacted the upstream miter gate in the main chamber at Greenup Locks and Dam (Figure B-1). It appeared that an approaching barge impacted the end fender guard transition pieces of the fender protection causing the plate to deform and welds to break (Figure 2-19 in Chapter 2 of this report). As the barge continued to rub down the side of the gate leaf, it caused the UHMWPE fender material to compress and severely damage or shear off the $3 / 4$-in. machine bolts used to attach the fender material to the gate (Figure B-2). The yellow UHMW fender protection material was severely gouged in several areas and has splintered and flaked due to being compressed (Figure B-3). The 5/8-in. steel diagonal protection plate was bowed in three locations that span the steel channel sections (Figure B-4). The rubber backing to the yellow fender protection appeared to have performed appropriately and was intact.

Huntington District structural engineers determined that the gate was not compromised due to the impact and recommended replacing the damaged fender material with the same yellow UHMWPE fender material as originally installed.

Figure B-1. Greenup Lock and Dam, main chamber upstream river wall leaf, view of damaged area.

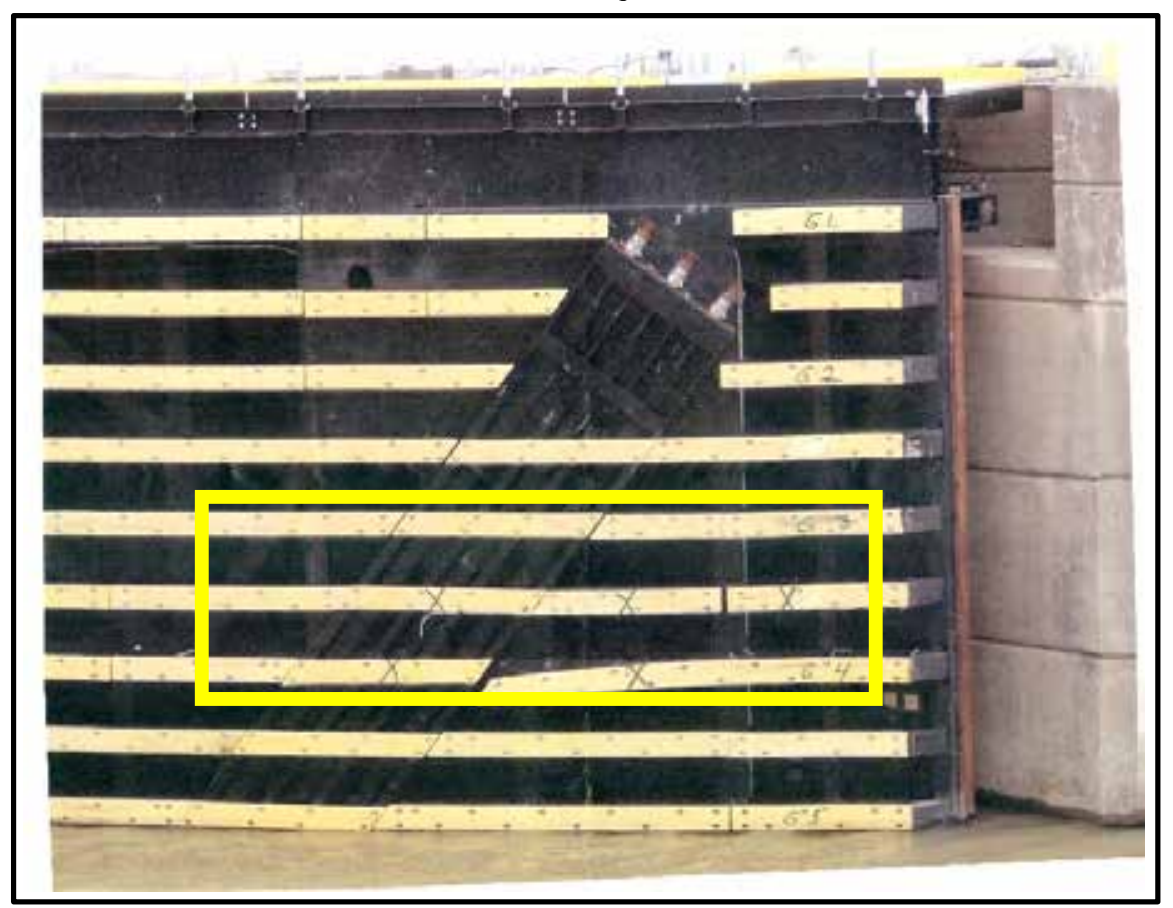


Figure B-2. Greenup Lock and Dam, main chamber upstream river wall leaf, view of sheared off machine bolt. Most bolts are bent or sheared off, but stayed in place.

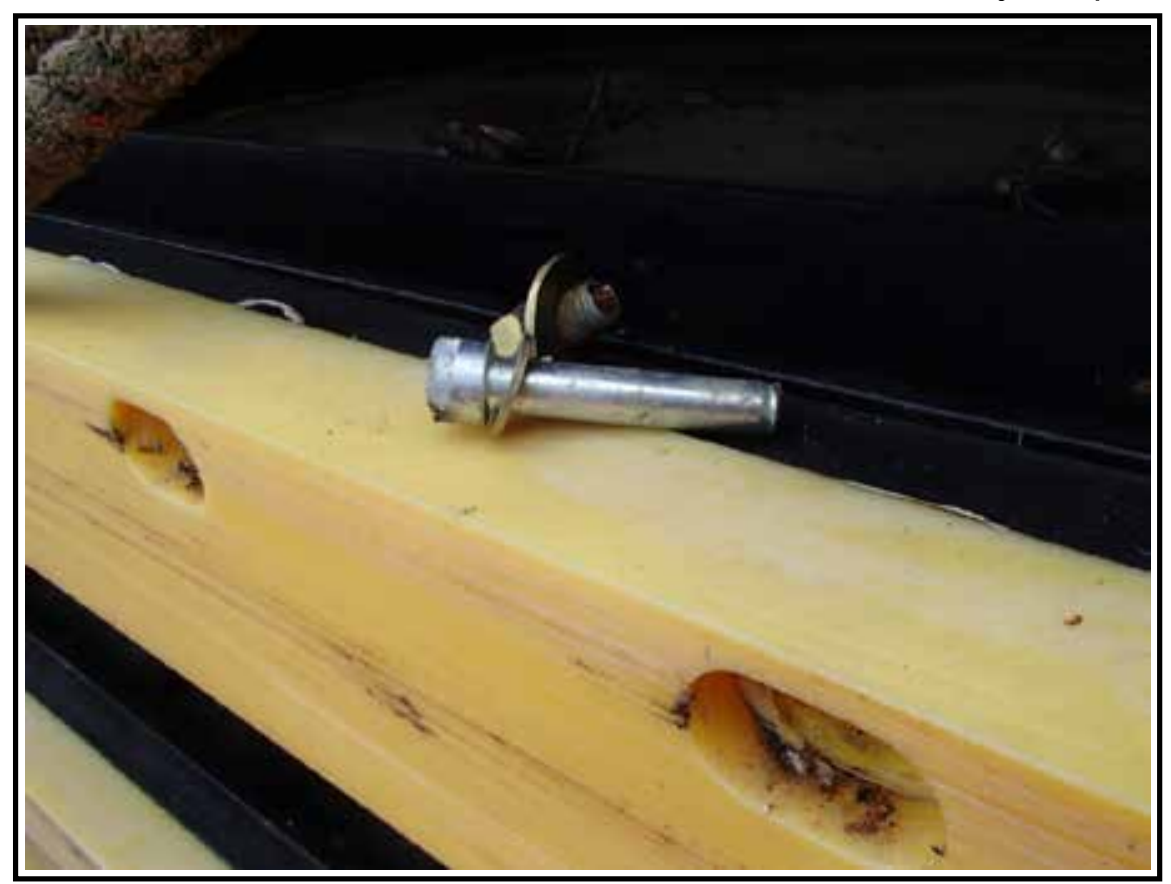

Figure B-3. View of gouges in UHMW fender.

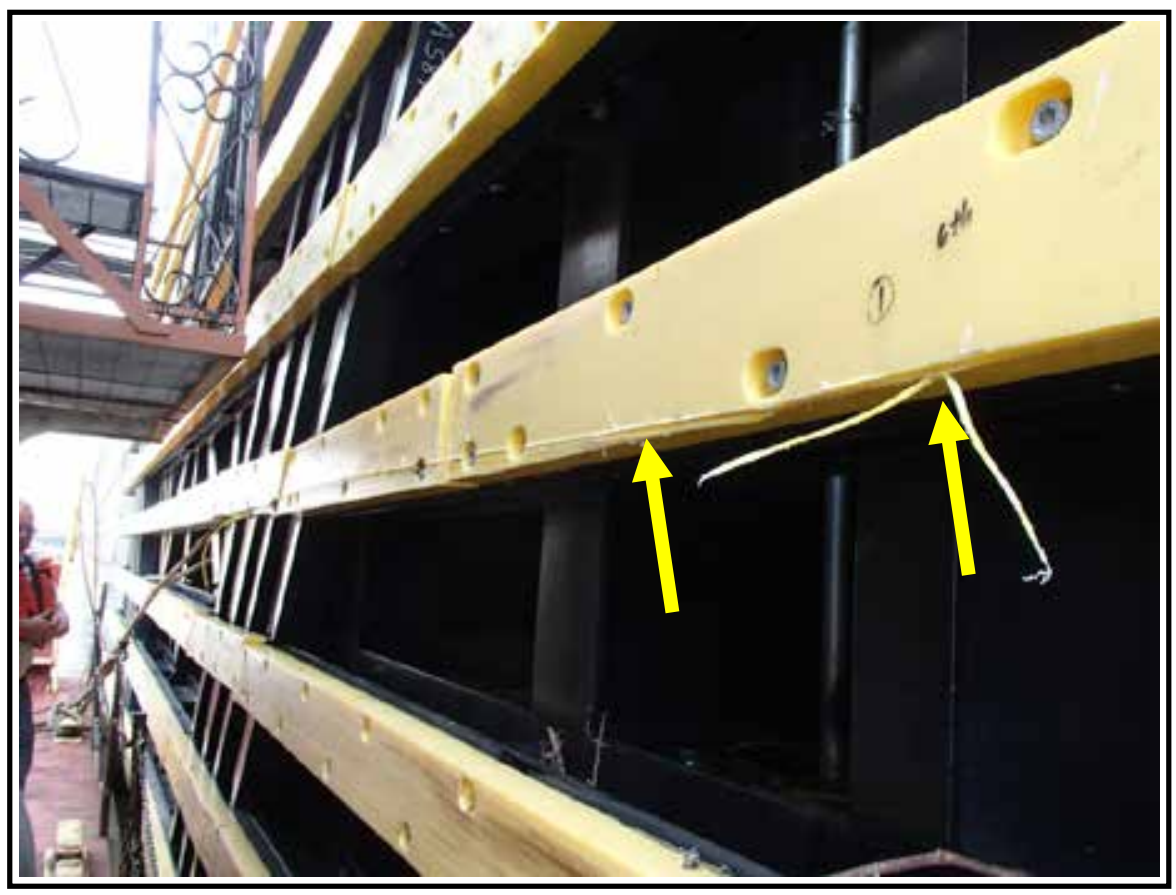


Figure B-4. Greenup Lock and Dam, main chamber upstream river wall leaf, view of bent protection plate over the diagonals.

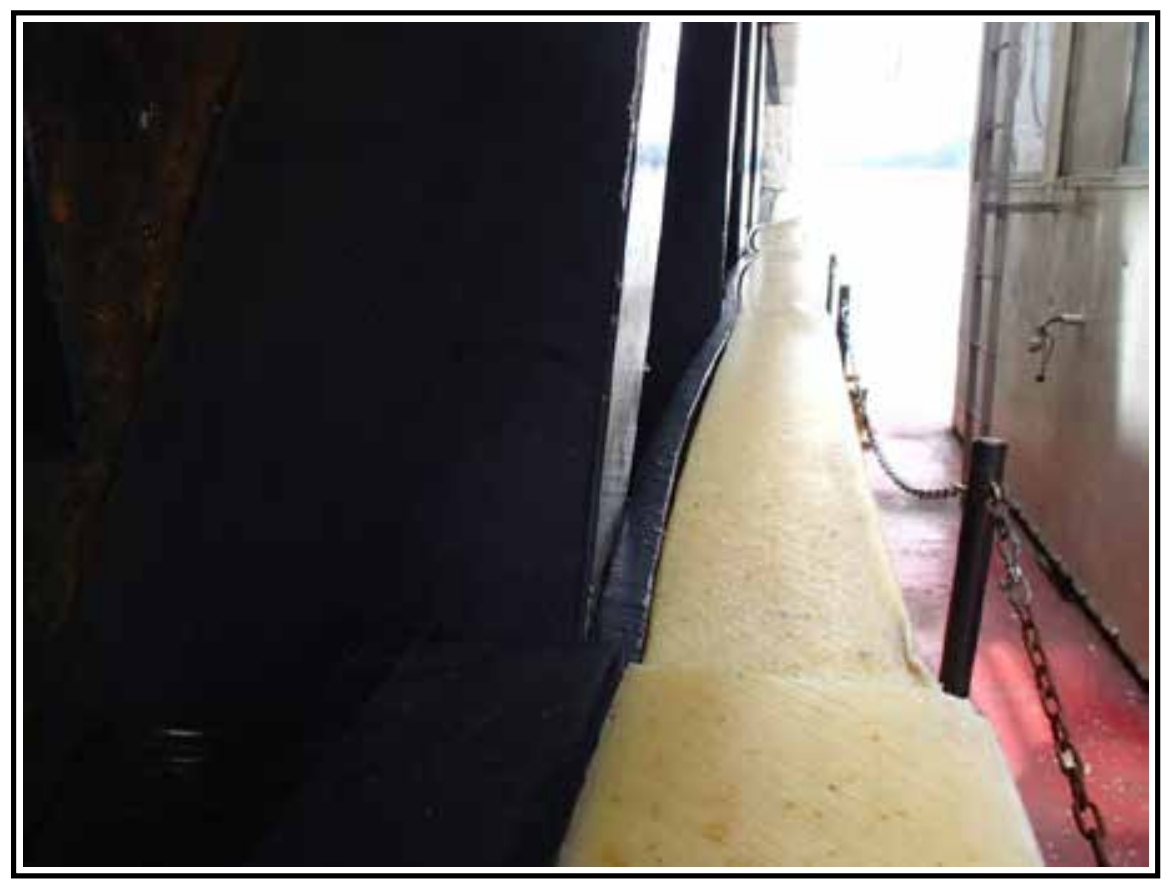




\section{Appendix C: Best Practices Meetings for Fenders}

As part of the selection process to replace existing fenders at Cannelton Locks and Dam, Louisville District contacted other Districts to get input on their experiences and preferences with different fender materials and systems. The following sections include notes from these meetings. Contact Russell (CELRL-EDD-N) at Louisville District for further information or details.

\section{C.1 2017-03-30 - Best Practices with LRH (Huntington)}

- Attendees:

o Kish (LRH)

o J ones (LRH)

- Fenders:

- Square tube sections

o Composite WT section with backing

o Stiffeners every 2 feet on fenders

o Problem with steel is that once it gets impacted it is no longer useful

\section{C.2 2017-03-30 - Best Practices with MVR (Rock Island)}

- Attendees:

o Jones (MVR)

o Johnson (MVR)

o DeLong (MVR)

o Stamper (INDC)

- Fenders:

o Illinois River uses polyethylene with fiberglass reinforcement rods - (J ohnson prefers); Reinforcement rods prevent sagging, which was common before reinforcement

o Rubber - with wear, they don't perform as well

o Don't use steel as much

o Mississippi River uses wood

o MVR will send (this) report to LRL

o Steel with neoprene backing is what J ohnson prefers for high traffic/ corrosion environments 


\section{C.3 2017-03-31 - Best Practices with LRP (Pittsburgh)}

- Attendees:

o Stamper (INDC)

o Dalton (INDC)

o DeCarlo (LRP)

o Fogel (LRP)

o Stoltz (LRP)

- Fenders:

o Have a mix of everything

* Steel channel with UHMW block

* Timber blocks

o UHMW is so hard that it transmits any impact directly into the gate; UHMW is great for wear and longevity

o Successful with steel fenders

\section{C.4 2017-03-31 - Best Practices with Jeff Ross of LRN (Nashville)}

- Attendees:

o Ross (LRN)

- Fenders:

o Some UHMW, mostly steel, some timber

- Obtuse angle that welds directly into the fender

- Second angle that's at an acute angle (40deg) that welds directly into the inner (obtuse) fender

o Acute angle (40deg) will break off before the weld of the obtuse angle to the girder flange

o Weld bar stop to the inside to give stiffness so that fender doesn't get damaged as easily

- See new design for Wilson L\&D

o Ross will send a sketch to LRL (see Figures C-1 and C-2).

o New Chickamauga lock will probably have UHMW fenders

o Old Kentucky Lock is timber

o Steel HSS with rubber and UHMW.

\section{C.5 2017-04-03 - Best Practices with LRN (Nashville)}

- Attendees:

o Bolter (Nashville)

o Tribble (Nashville)

o Morgan (Nashville) 
- Fenders:

o Some timber, some steel, some UHMW

o Latest designs UHMW blocks with rubber backing

o Don't absorb as much impact as steel, but rubber helps absorb

o Timbers work fine

o Steel fenders need to be compressible

o Trend forward seems to be UHMW

o Issue with UHMW is temperature (perhaps related to specs during fabrication; LRN recommends oversizing holes to prevent shearing bolts during contraction/ elongation due to temperature changes)*

\section{C.6 2017-04-05 - Best Practices with St. Louis (MVS)}

- Attendees:

o Kelsey (MVS)

o Adden (MVS)

- Fenders:

o All miter gates in the last 20 years use UHMW

o UHMW works well if barge hits it with a glancing blow; However, UHMW does not absorb direct blows, therefore the girder flanges get damaged

o Put southern yellow pine on a gate

* Timber would shatter

* Gate base steel was left intact

* Wood absorbs more energy than UHMW

* Can treat with CCA Arsenic (legal) ${ }^{\dagger}$

o MVS are converting their miter gates back to [Southern Yellow Pine] wooden fenders bolted through the flange

o Usually replace about 1 to 2 wooden fenders per year based on normal wear

* Major impacts require additional replacement

* Quick and easy to replace

o See fenders at Soo Locks [Fenders at Soo Locks are Douglas Fir.]

\footnotetext{
${ }^{*}$ Note from report authors - It is unclear what this parenthetical refers to. See Sections 2.2 .5 and 2.3 for further discussion of bolting plastic lumber.

† Note from report authors - The use of CCA treated wood was voluntarily discontinued for residential use in 2003. CCA can leach arsenic into the environment throughout its life, While still approved for commercial and industrial use, CCA treated wood timbers should be used and disposed of with caution.
} 


\section{C.7 2017-04-06 - Best Practices with Mobile (SAM)}

- Attendees

o Saucer (SAM)

o Brewer (SAM)

o Davis (SAM)

o Stamper (INDC)

o Perkins (SAM Operations)

- Fenders:

- UHMW composite material with 2" of rubber behind

* Been using for at least 10 years now

- SAM has used some UHMW fenders without rubber backing

* Easy to procure

* Shorter delivery times

* Easier to work with

o Some still have timber fenders, but are replaced with UHMW

Figure C-1. Wilson L\&D fender design.

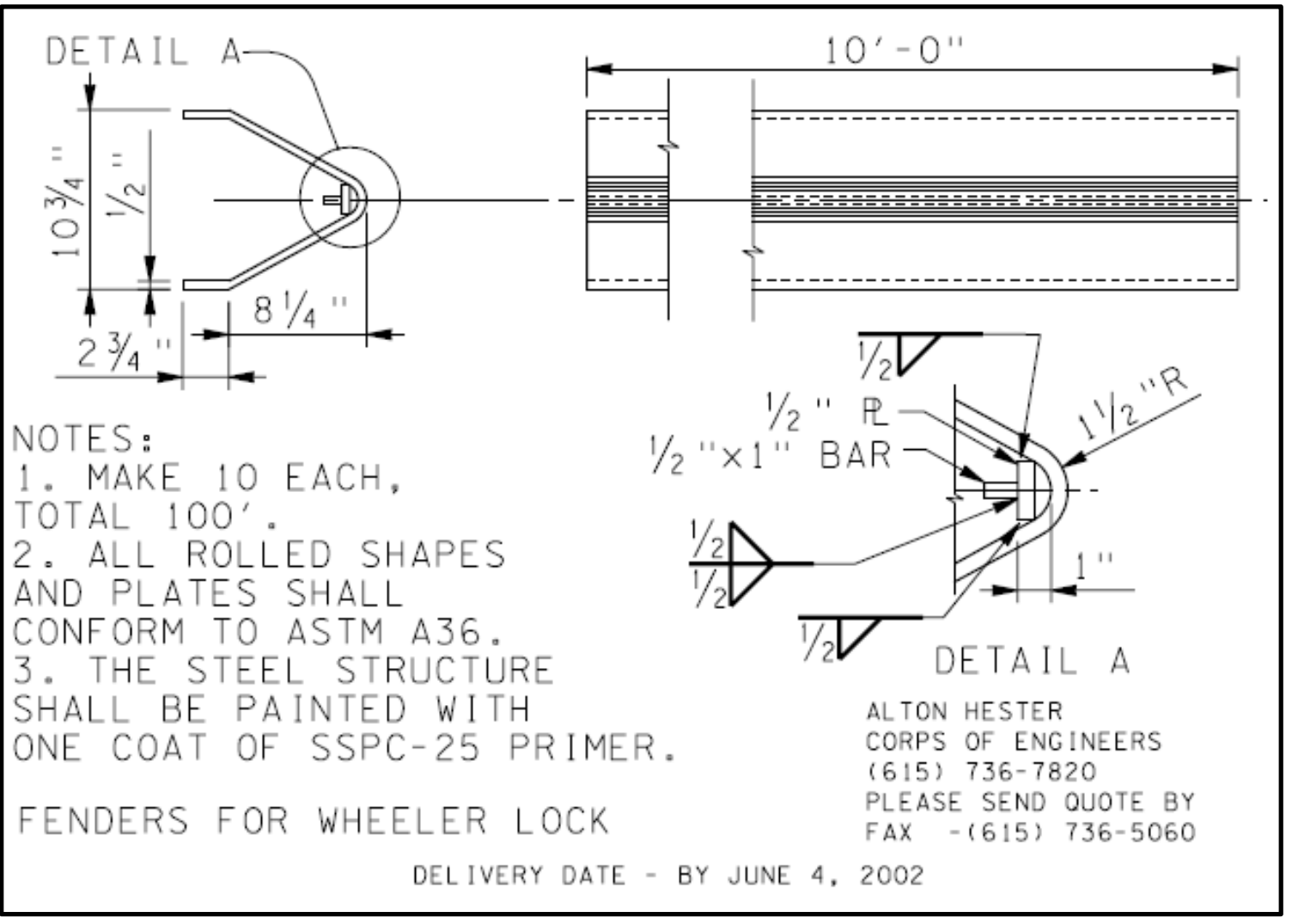


ERDC/ CERL TR-17-37

39

Figure C-2. Proposed CELRN fender design.

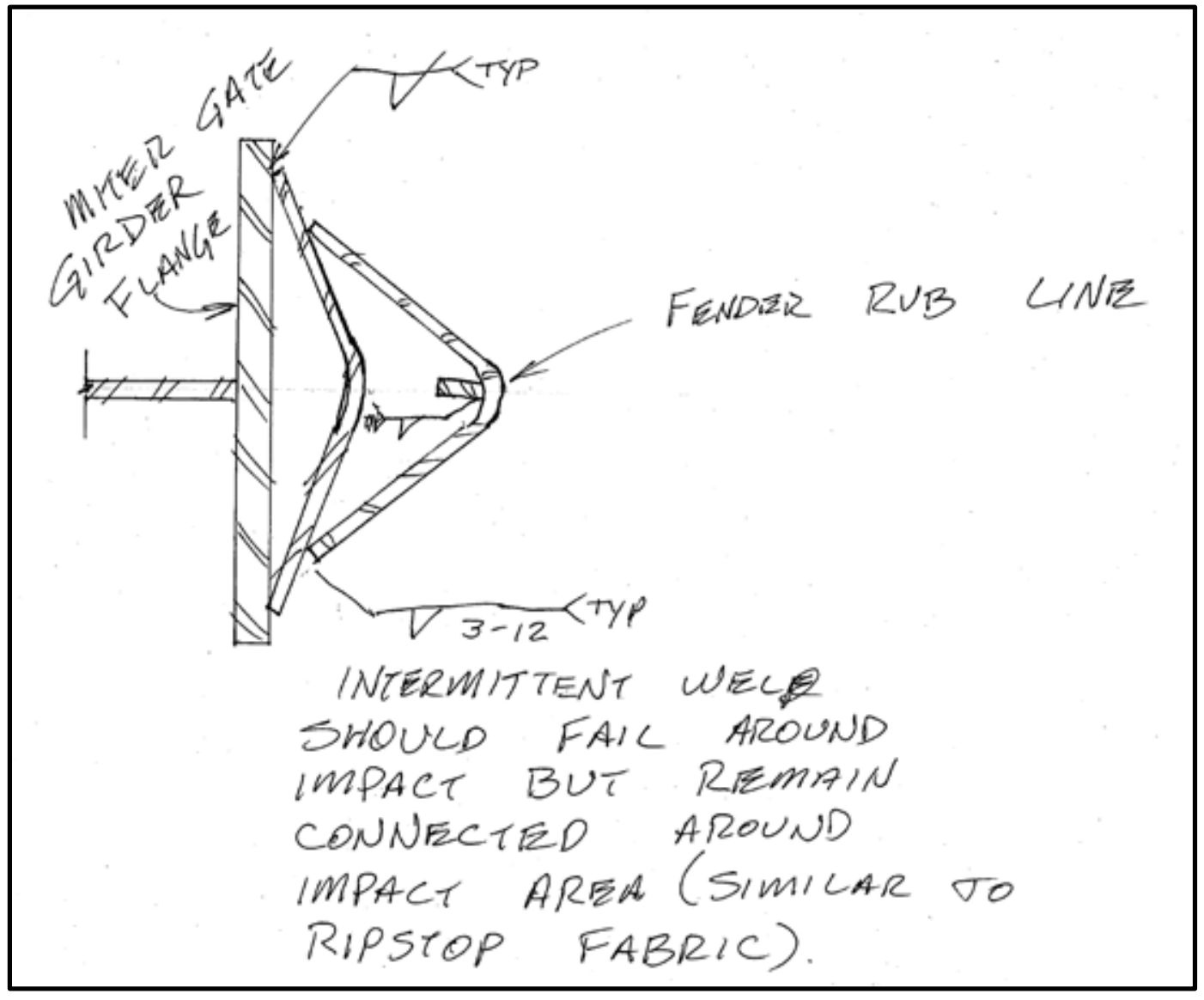




\section{References}

*Arroyo, J osé Ramón, and Robert M. Ebeling. 2004. A Numerical Method for Computing Barge Impact Forces Based on Ultimate Strength of the Lashings between Barges. ERDC/ ITL TR-04-2. Vicksburg, MS: ERDC-ITL, http:/ / acuc.sdp.sirsi.net/ dient/ search/ asset/ 1003662

*Arroyo, J osé Ramón, and Robert M. Ebeling. 2005. Barge Train Maximum Impact Forces Using Limit States for the Lashings between Barges. ERDC/ ITL TR-05-1, Vicksburg, MS: ERDC-ITL, http:/ / acwc.sdp.sirsi.net/ dient/ search/ asset/ 1003665

*Arroyo, J osé Ramón, Robert M. Ebeling, and Bruce C. Barker. 2003. Analysis of Impact Loads from Full-Scale, Low-Velocity, Controlled Barge Impact Experiments. ERDC/ ITL TR-03-3. Vicksburg, MS: ERDC-ITL, http:// acuc.sdp.sirsi/ net/ dient/ search/ asset/ 1003656

*Arroyo-Caraballo, J osé R., and Robert M. Ebeling. 2006. Glancing blow impact forces by a barge train on a lock approach wall. J ournal of Infrastructure Systems 12(2):135-143, http:/ / cedb.asce.org/ cgi/ WuWbisplay.cgi?152600

Ebeling, Robert M., Barry White, Richard Lampo, and Thomas Hood. 16 December 2014. Summary of the 19 November 2014 Dredging Operations Technical Support Program (DOTS) Sponsored Visit to Galveston District and Brazos River Floodgates Project. Letter Report from ERDC-ITL to Mr. Karl Brown, Galveston District (CESWG-OD-N).

*Consolazio, Gary R., J ohn R. Wilkes, and Charles R. Rodrigues. 2014. Determination of Barge Flotilla Impact Loads on Pile Founded Concrete Guide Walls \& Development of a Unified Impact Load Prediction Model for Navigational Structures. Structures Research Report 2014/ 104971. Gainesville, FL: University of Florida Civil and Coastal Engineering, http:// wwwimpact.essie.ufl.edu/ doc/UF-report-2014-104971.pdf

*Ebeling, Robert M., Abdul N. Mohamed, J ose R. Arroyo, Barry C. White, Ralph W. Strom, and Bruce C. Barker. 2011. Dynamic Structural Flexible-Beam Response to a Moving Barge Train Impact Force Time-History Using Impact Beam. ERDC/ITL TR-11-1. Vicksburg, MS: ERDC-ITL, http:// achc.sdp.sirsi.net/ dient/ search/ asset/ 1003678

*Ebeling, Robert M., and Terry W. Warren. 2008. Limiting Impact Force Due to Yielding and Buckling of the Plates and Internal Structural Frame at the Impact Corner of the Barge during Its Glancing Blow Impact with a Lock Approach Wall. ERDC/ITL TR-08-2. Vicksburg, MS: ERDC-ITL, http:/ / achc.sdp.sirsi.net/ dient/ search/ asset/ 1003671

\footnotetext{
* Studies on damage resulting from large impacts by barges that cause substantial gate damage where fenders do little or nothing to mitigate are indicated by an asterisk.
} 
*Ebeling, Robert M., Barry C. White, Abdul N. Mohamed, and Bruce C. Barker. 2010. Force Time History during the Impact of a Barge Train with a Lock Approach Wall Using Impact Force. ERDC/ ITL TR-10-1, Vicksburg, MS: ERDC-ITL, http:// achc.sdp.sirsi.net/ dient/ search/ asset/ 1003677

*Ebeling, Robert M., Barry C. White, Ralph W. Strom, J ohn E. Hite, Jr., Bruce C. Barker, and Richard W. Haskins, Deformable Bullnose Energy Absorbing System (BEAS), report 2, Head-on impact with a deformable BEAS and introducing a collapsible arch ERDC TR-11-5, July 2011. Vicksburg, MS: ERDC-ITL, http:// acuc.sdp.sirsi.net/ dient/ search/ asset/ 1002776

*Ebeling, Robert M., J ohn E. Hite, J r., Ralph W. Strom, and Barry C. White. 2010. Deformable Bullnose Energy Absorbing System (BEAS): Report 1, Initial Development and Concept Design. ERDCTR-10-7. Vicksburg, MS: ERDC-ITL, http:/ / achc.sdp.sirsi.net/ dient/ search/ asset/ 1002769

*Ebeling, Robert M., Ralph W. Strom, Barry C. White, and Kevin Abraham. 2012. Simplified Analysis Procedures for Flexible Approach Wall Systems Founded on Groups of Piles and Subjected to Barge Train Impact. ERDC/ ITL TR-12-3. Vicksburg, MS: ERDC-ITL, http:/ / acwc.sdp.sirsi.net/ dient/ search/ asset/ 1010100

Federal Highway Administration/ National Highway Transportation Safety Administration (FHA/ NHTSA). 2000. Public Finite Element Model Archive: Vehicle Models. Washington, DC: FHA/NHTSA, National Crash Analysis Center, http:// unw.ncac.gun.edu

Headquarters, U.S. Army Corps of Engineers (HQUSACE). Barge impact analysis for rigid walls. Engineer Technical Letter 1110-2-563. Washington, DC: U.S. Department of the Army. 2004. [EXPIRED]

Lindgren, Ralph M. 1953. An Overall Look at Wood Deterioration. Report No. 1966. Madison, WI: U.S. Department of Agriculture, Division of Forest Pathology, Madison Branch, http:// ir.library.oregonstateed / xmlu/ / bitstream/ handle/ 1957/2422/ PPL 196600.pdf? sequence=1

*Patev, R. C., B. B. Barker, and L. V. Koestler. 2003. Full-Scale Barge Impact Experiments, Robert C. Byrd Lock and Dam, Gallipolis Ferry, West Virginia. ERDC/ ITL TR-03-7. Vicksburg, MS: ERDC-ITL, http:/ / acuc.sdp.sirsi.net/ dient/ en_US/ search/ asset/ 1003660

*Patev, Robert C, Bruce C. Barker, and Leo V. Koestler. 2003. Prototype Barge Impact Experiments, Allegheny Lock and Dam 2, Pittsburgh, Pennsylvania, ERDC/ITL TR-03-2. Vicksburg, MS: Engineer Research and Development Center, Information Technology Laboratory (ERDC-ITL), http:// acuc.sdp.sirsi.net/ dient/ en_US/ search/ asset/ 1003655

*Permanent International Association of Navigation Congresses (PIANC). 2014. Design of Lock Gates for Ship Collision. PIANC Report No 151, International Standard Book Number (ISBN) 978-2-87223-215-4. Brussels, Belgium: PIANC.

Schuyler Companies. 2011. Marine Fenders: Docks, Piers, Piles, Bridge Abutments. Brochure. Broussard, LA: Schuyler Companies, http:/ / wwwschuslerco.com/ pdfs/Schusler\%20Companies\%20-\%20Dock\%20Fenders.pdf 
Schuyler Companies. 2004. General Specifications for Laminated Rubber Fenders. Brochure. Broussard, LA: Schuyler Companies, http:/ / file.seekpart com/ keywordpdf/ 2011/ 1/ 11/2011111141429689.pdf

Trelleborg Marine Systems. 2017. Fender Systems. Product Brochure. BC-FEN-v3.3-EN. Trelleborg, Sweden: Trelleborg AB, http:// wuwtrelleborg.com/ marine systems/ / media/ marinesystems/resources/brochures/ downloads/ fender systems ver3 3.pdf

Trelleborg Marine Systems. 2016. Fender Application Design Manual. Design Manual. MN-ADM-v2.1-EN. Trelleborg, Sweden: Trelleborg AB, http:// uwwtrelleborg.com/ marine-systems/ / media/ marine-systems/ resources/ guides--and-design-manual/downloads/ fadesignmanual_V2_14_sp.pdf

Wuttrich, Rafal, J erry Wekezer, Nur Yazdani, and Claudia Wilson. 2001. Performance evaluation of existing bridge fenders for ship impact. J ournal of Performance of Constructed Facilities 15(1):17-23. 


\section{Acronyms and Abbreviations}

$\begin{array}{ll}\text { Term } & \text { Definition } \\ \text { ANSI } & \text { American National Standards Institute } \\ \text { ASTM } & \text { American Society for Testing and Materials } \\ \text { BEAS } & \text { Bullnose Energy Absorbing System } \\ \text { CELRL } & \text { U.S. Army Corps of Engineers, Louisville District } \\ \text { CERL } & \text { Construction Engineering Research Laboratory } \\ \text { ERDC } & \text { U.S. Army Engineer Research and Development Center } \\ \text { ERDC-CERL } & \text { Engineer Research and Development Center, Construction Engineering } \\ & \text { Research Laboratory } \\ \text { ERDC-ITL } & \text { Engineer Research and Development Center, Information Technology } \\ & \text { Laboratory } \\ \text { HDPE } & \text { High Density Polyethylene } \\ \text { HQUSACE } & \text { Headquarters, U.S. Army Corps of Engineers } \\ \text { ISBN } & \text { Intemational Standard Book Number } \\ \text { NSN } & \text { National Supply Number } \\ \text { OMB } & \text { Office of Management and Budget } \\ \text { PI } & \text { Principal Investigator } \\ \text { PIANC } & \text { Permanent International Association of Navigation Congresses } \\ \text { SAR } & \text { Same As Report } \\ \text { SF } & \text { Standard Form } \\ \text { TR } & \text { Technical Report } \\ \text { UHMWPE } & \text { Ultra-High Molecular Weight Polyethylene } \\ \text { USACE } & \text { U.S. Army Corps of Engineers } \\ \text { UV } & \text { Ultraviolet } \\ & \\ & \end{array}$




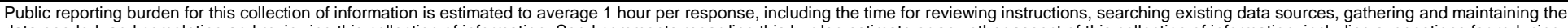

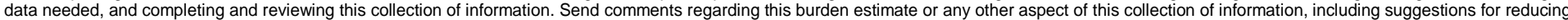

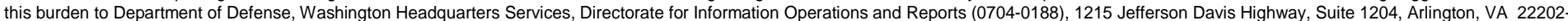

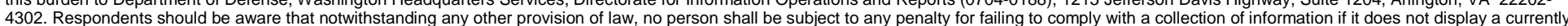
4302. Respondents should be aware that notwithstanding any other provision of law, no person shs.
valid OMB control number. PLEASE DO NOT RETURN YOUR FORM TO THE ABOVE ADDRESS.

\begin{tabular}{l|l} 
valid OMB control number. PLEASE DO NOT RETURN YOUR FORM TO THE ABOVE ADDRESS. \\
\hline 1. REPORT DATE (DD-MM-YYYY)
\end{tabular}
1. REPORT DATE(DDIMIM-Y
$11 / 01 / 2017$
2. REPORT TYPE
Final

4. TITLE AND SUBTITLE

Material Selection for Bumpers and Fenders for Lock Gates and Guidewalls

3. DATES COVERED (From - To)

5a. CONTRACT NUMBER

5b. GRANT NUMBER

5c. PROGRAM ELEMENT

6. AUTHOR(S)

Richard G. Lampo and Stuart D. Foltz

\section{5d. PROJECT NUMBER}

5e. TASK NUMBER

5f. WORK UNIT NUMBER

7. PERFORMING ORGANIZATION NAME(S) AND ADDRESS(ES)

U.S. Army Engineer Research and Development Center (ERDC)

Construction Engineering Research Laboratory (CERL)

PO Box 9005,

Champaign, IL 61826-9005

8. PERFORMING ORGANIZATION REPORT NUMBER

ERDC/CERL TR-17-37

\section{SPONSORING / MONITORING AGENCY NAME(S) AND ADDRESS(ES)}

Headquarters, U.S. Army Corps of Engineers

440 G Street, NW

Washington, DC 20314-1000

10. SPONSOR/MONITOR'S ACRONYM(S)

CEERD-HT

11. SPONSOR/MONITOR'S REPORT NUMBER(S)

\section{DISTRIBUTION I AVAILABILITY STATEMENT}

Approved for public release; distribution is unlimited.

\section{SUPPLEMENTARY NOTES}

\section{ABSTRACT}

The U.S. Army Corps of Engineers owns or operates 236 locks at 191 sites, more than half of which have surpassed their 50-year design life. There are increasing concerns about their continued safe, reliable operation into the future, especially regarding the adequacy, cost, and effectiveness of routine maintenance, repair, and rehabilitation. Lock gate and guidewall fenders are components that protect locks and gates from barge impacts, and that are consequently subject to impact damage as well as environmental degradation. Fenders may be constructed of any of several materials, most commonly wood, steel, or plastic. The Corps has used fenders made of plastic and composite alternatives to wood and steel shapes with varying levels of success. It is useful to evaluate these newer plastic/composite materials, and to compare them with their traditional counterparts to determine their relative merits. This preliminary study, based on survey results, was undertaken to initiate an investigation into and discussion of the materials and designs currently used for lock gate and guidewall fenders, with a focus on their relative advantages and disadvantages.

\section{SUBJECT TERMS}

Hydraulic structures, Locks (Hydraulic engineering)--Maintenance and repair, Materials--Evaluation

\section{SECURITY CLASSIFICATION OF:}

\section{a. REPORT}

Unclassified

\section{b. ABSTRACT}

Unclassified

\section{LIMITATION} OF ABSTRACT

c. THIS PAGE

Unclassified
SAR

\section{NUMBER} OF PAGES

52 19a. NAME OF RESPONSIBLE PERSON

19b. TELEPHONE NUMBER

(include area code) 